Synthesis, Structures, and Electronic Properties of O- and S-Heterocyclic Carbene Complexes of Iridium, Copper, Silver, and Gold

\author{
Joost, Maximilian
}

2020-05-26

Joost , M , Nieger , M , Lutz , M , Ehlers , A W , Slootweg , J C \& Lammertsma , K 2020 , ' Synthesis, Structures, and Electronic Properties of O- and S-Heterocyclic Carbene Complexes of Iridium, Copper, Silver, and Gold ' , Organometallics , vol. 39 , no. 10 , pp. 1762-1771 . https://doi.org/10.1021/acs.organomet.0c00066

http://hdl.handle.net/10138/316994

https://doi.org/10.1021/acs.organomet.0c00066

cc_by

publishedVersion

Downloaded from Helda, University of Helsinki institutional repository.

This is an electronic reprint of the original article.

This reprint may differ from the original in pagination and typographic detail.

Please cite the original version. 


\section{Synthesis, Structures, and Electronic Properties of O- and S-Heterocyclic Carbene Complexes of Iridium, Copper, Silver, and Gold}

Maximilian Joost, Martin Nieger, Martin Lutz, Andreas W. Ehlers, J. Chris Slootweg, and Koop Lammertsma*

Cite This: Organometallics 2020, 39, 1762-1771

Read Online

ACCESS | Lلll Metrics \& More | 国 Article Recommendations | st Supporting Information

ABSTRACT: O- and S-heterocyclic carbenes (OHCs, SHCs) are shown experimentally and computationally to be stronger $\pi$ acceptors than NHCs and lack, of course, substituents at the heteroatoms. These different electronic and steric characteristics make OHCs and SHCs interesting ligands for coordination chemistry. Convenient synthetic routes are presented to access their iridium(I), iridium(III), and coinage-metal(I) $(\mathrm{Cu}, \mathrm{Ag}, \mathrm{Au})$ complexes in good yields by means of dissociation of olefins, deprotonation of precursor salts, and transmetalation from a silver carbene complex. Molecular structures and detailed bonding analyses of these complexes are presented.

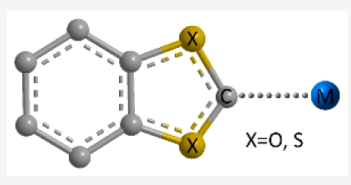

N-heterocyclic carbenes (NHCs, I, Figure 1$)^{1}$ have had a profound impact on organic synthesis, ${ }^{2}$ catalysis, $^{3}$ and

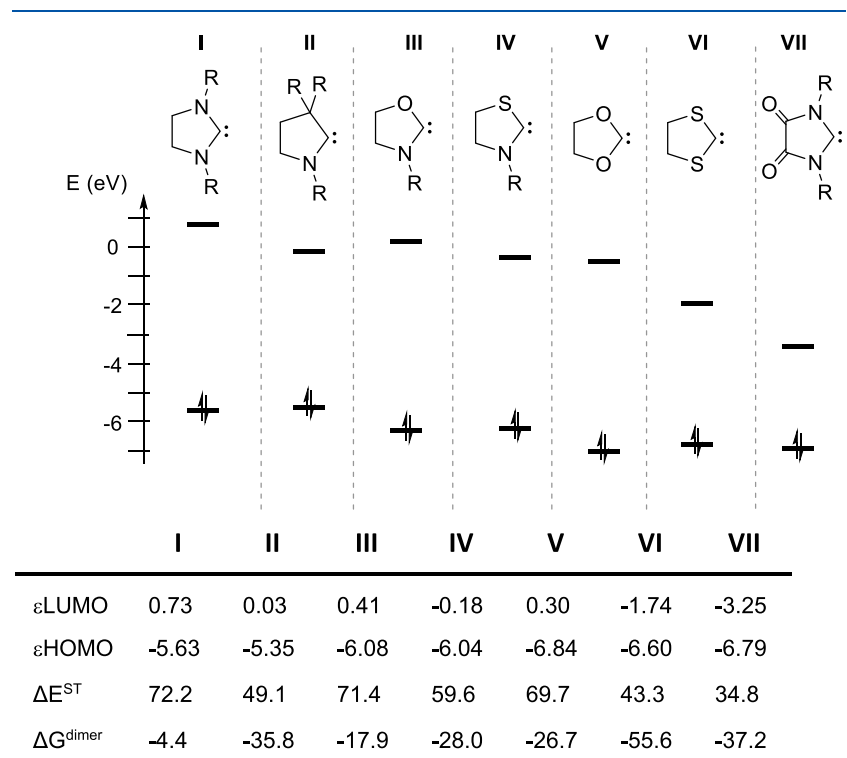

Figure 1. HOMO and LUMO energies (in $\mathrm{eV}$, also visualized), singlet-triplet energy gaps $\left(\Delta E^{S T}\right.$ in $\left.\mathrm{kcal}^{\mathrm{mol}}{ }^{-1}\right)$, and Gibbs free energies of dimerization (in $\mathrm{kcal} \mathrm{mol}^{-1}$ ) for carbenes $\mathbf{I}-\mathrm{VII}$ with $\mathrm{R}=$ Me at the B3LYP/TZVP level.

materials research. ${ }^{4}$ The strong $\sigma$-donor and $\pi$-acceptor properties of the NHCs underlie the stability of their transition-metal (TM) complexes. ${ }^{5}$ These Fischer-type carbene complexes have been heavily explored for catalysis by electronic and steric tuning of the ligands, ${ }^{6}$ such as modifying the backbone to cyclic diamidocarbenes (VII), which are strongly $\pi$ back-bonding, but also by replacing an NR for a $\mathrm{CR}_{2}$ unit as in cyclic alkylaminocarbenes (CAACs, II $)^{7}$ and cyclic aminoarylcarbenes (CAArCs). ${ }^{8}$ Whereas replacing NR units for oxygen or sulfur atoms should likewise have a substantial effect, it is surprising that the NOHCs (III) ${ }^{9}$ and NSHCs (IV) ${ }^{10}$ have been explored far more modestly. ${ }^{11}$

This study focuses on $\mathrm{O}$ - and S-heterocyclic carbenes (OHCs (V) and SHCs (VI)) in which both NR units of the $\mathrm{NHC}$ are exchanged for $\mathrm{O}$ or $\mathrm{S}$ atoms. The coordination of these carbenes is, a priori, determined by electronic stabilization only, which is in contrast with any of the NHCs (I-IV), where the fanlike behavior of the $\mathrm{N}$ substituents contributes to steric shielding of the transition metal. ${ }^{6 a}$

The electronic donor/acceptor properties of the $\mathrm{OHC}$ and SHC carbenes can be inferred from the relative energies of the frontier orbitals, which are compared in Figure 1 with those of the more familiar NHCs (I) and CAACs (II) as well as the NOHCs (III) and NSHCs (IV) and the cyclic diamidocarbenes (VII) at the B3LYP/TZVP level $(\mathrm{R}=\mathrm{Me})$ (see the Supporting Information for details).

The low energies of the carbene-centered HOMOs suggest OHCs and SHCs to be the weakest $\sigma$-donating ligands of the set, only similar to diamidocarbene VII. The $\pi$-acceptor ability of the carbenes increases from left to right in Figure 1 as the carbene-centered LUMO decreases in energy. The singlettriplet energy difference $\left(\Delta E^{S T}\right)$, which is a measure for the

Received: January 30, 2020

Published: May 8, 2020 
stability of a carbene, is a significant $69.7 \mathrm{kcal} \mathrm{mol}^{-1}$ for $\mathrm{OHC}$ and similar in magnitude to that of NHC I, while the smaller value for SHCs $\left(43.3 \mathrm{kcal} \mathrm{mol}{ }^{-1}\right.$ ) resembles that of diamidocarbene VII. The large difference in dimerization energies $\left(\Delta G^{\text {dimer }}\right)$ of OHCs $\left(-26.7 \mathrm{kcal} \mathrm{mol}^{-1}\right)$ and SHCs $\left(-55.6 \mathrm{kcal} \mathrm{mol}^{-1}\right)$ also suggests a higher stability for $\mathrm{OHCa}$, as values of over $-50 \mathrm{kcal} \mathrm{mol}^{-1}$ are indicative of reactive carbenes. $^{12}$ The calculations imply that OHCs and SHCs complement the range of available heterocyclic carbene ligands.

A number of $\mathrm{OHC}^{13}$ and SHC complexes ${ }^{13 i, 1,14}$ have been reported in the literature. To enhance their general accessibility and possibly boost their applicability, we present here three synthetic routes, akin to those developed for NHCs, to access OHC and SHC TM complexes, report on their molecular structures, and quantify their electronic characteristics.

We decided to compare the benzannulated derivatives of OHC $\left(\mathbf{1}^{\mathbf{O}}\right)$ and SHC $\left(\mathbf{1}^{\mathbf{s}}\right)$ to the NMe-substituted NHC $\left(\mathbf{1}^{\mathbf{N}}\right)$ (Figure 2). Their $\pi$-acceptor abilities can be estimated with the

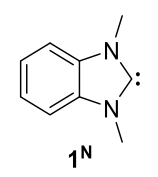<smiles>c1ccc2c(c1)OCO2</smiles>

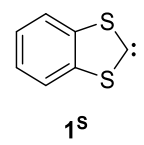

Figure 2. Benzannulated $\mathrm{NHC}, \mathrm{OHC}$, and $\mathrm{SHC}$ heterocyclic carbenes 1 with their respective superscript notations $\mathrm{N}, \mathrm{O}$, and S.

help of selenium adducts (Scheme 1), the electronic properties of which correlate with the ${ }^{77} \mathrm{Se}$ NMR chemical shifts; the more deshielded species correspond to the more strongly accepting carbenes. ${ }^{15}$

Scheme 1. Synthesis of Selones $1^{\mathrm{N}}-\mathrm{Se}, 1^{\mathrm{O}}-\mathrm{Se}$, and $1^{\mathrm{S}}-$ Se with ${ }^{77}$ Se NMR Shifts

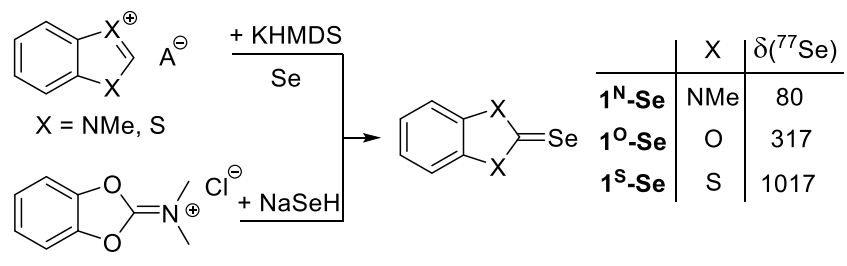

The synthesis of the selones of $\mathbf{1}^{\mathbf{N}}, \mathbf{1}^{\mathrm{O}}$, and $\mathbf{1}^{\mathrm{S}}$ is shown in Scheme 1 together with the observed ${ }^{77} \mathrm{Se}$ NMR chemical shifts. These follow the order $\mathbf{1}^{\mathrm{N}}-\mathrm{Se}<\mathbf{1}^{\mathrm{O}}-\mathrm{Se}<\mathbf{1}^{\mathrm{S}}$-Se in accord with their calculated LUMO energies (see the Supporting Information). The chemical shifts for $\mathbf{1}^{\mathrm{N}}-\mathrm{Se}(80 \mathrm{ppm})$ and $\mathbf{1}^{\mathrm{O}}$ Se $(317 \mathrm{ppm})$ are well within the -20 to $800 \mathrm{ppm}$ range for known carbene-Se adducts and reflect $\mathrm{OHC}$ to be the stronger $\pi$ acceptor. To the best of our knowledge, $\mathbf{1}^{\mathrm{S}}$-Se has the most deshielded shift of 1017 ppm (!), suggesting this carbene to be by far the strongest $\pi$ acceptor.

Carbene TM complexes are commonly generated by dissociating an alkene, deprotonating a precursor salt, or transmetalating a carbene from a silver complex. ${ }^{16}$ For OHCs the instability of the dioxolium salts adversely affects the deprotonation route and the access to $\mathrm{Ag}$ complexes. Therefore, the splitting of an olefin was chosen as the starting point for the Ir complexes.

\section{Ir COMPLEXES}

Treating a solution of dibenzotetraoxofulvalene (DBTOF) ${ }^{17}$ in toluene with $\left[\operatorname{IrCl}_{2}(\operatorname{cod})\right]_{2}$ (cod $=1,5$-cyclooctadiene) for 4 days at room temperature gave the red $\mathrm{Ir}(\mathrm{I}) \mathrm{OHC}$ complex $2^{\mathrm{O}}$ in $58 \%$ yield (Scheme 2 ), but SHC complex $2^{\mathrm{S}}$ could not be

Scheme 2. Synthesis of the $\operatorname{Ir}(\mathrm{I})$ Complex $2^{\mathrm{O}}$

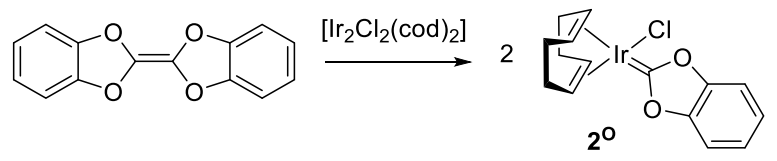

obtained in this manner from dibenzotetrathiofulvalene (DBTTF) likely due to its larger dimerization energy; ${ }^{18}$ $\left[\operatorname{IrCl}(\operatorname{cod}) \mathbf{1}^{\mathbf{N}}\right]\left(\mathbf{2}^{\mathbf{N}}\right)$ was prepared via an established procedure $^{19}$ (93\%; see the Supporting Information). The ${ }^{13} \mathrm{C}$ NMR spectra show a more deshielded carbene carbon for $2^{\mathrm{O}}$ $(\delta 209.2 \mathrm{ppm})$ than for $\mathbf{2}^{\mathbf{N}}(\delta 192.0 \mathrm{ppm})$, in accordance with the stronger $\pi$-accepting ability of the OHC ligand. ${ }^{20}$ The molecular structures, determined by single-crystal X-ray structure determinations, confirmed the formation of the $\mathrm{Ir}(\mathrm{Cl})(\mathrm{cod})$ OHC complex $2^{\mathrm{O}}$ and its NHC analogue $2^{\mathbf{N}}$ (Figure 3 ). The observed $\mathrm{Ir}-$ carbene bond distance of

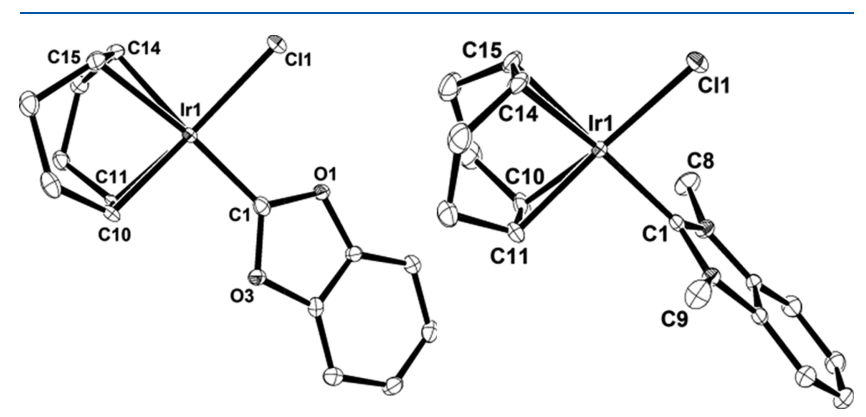

Figure 3. Structures of $2^{\mathrm{O}}$ (left) and $2^{\mathrm{N}}$ (right) in the crystal form. Ellipsoids are set at $50 \%$ probability; $\mathrm{H}$ atoms and solvent molecules are omitted for clarity. Selected bond lengths $(\AA)$ and angles (deg): $2^{\mathrm{O}}$, Ir1-C2 1.940(3), Ir1-C10 2.112(3), Ir1-C11 2.131(2), C14C15 1.379(4), C10-C11, 1.426(4), Ir1-C14 2.226(3), Ir1-C15 2.276(3), Ir1-Cl1 2.3531(6), O1-C2 1.349(3), C2-O3 1.346(3), C2-Ir1-Cl1 91.67(7), O3-C2-O1 108.7(2); $\mathbf{2}^{\mathrm{N}}, \quad \operatorname{Ir} 1-\mathrm{C} 1$ 2.0226(19), Ir1-C10 2.106(2), Ir1-C11 2.1120(19), C14-C15 1.383(3), C10-C11, 1.413(3), Ir1-C14 2.1860(19), Ir1-C15 2.2061(19), Ir1-Cl1 2.3585(5), N1-C1 1.359(2), C1-N2 1.357(2), C1-Ir1-Cl1 88.76(5), N1-C1-N2105.66 (16).

$1.940(3) \AA$ in $2^{\mathrm{O}}$ is shorter than the 2.0226(19) $\AA$ in $2^{\mathrm{N}}$ (1.925 versus $1.994 \AA$ at the BP86-D3/TZ2P level), which is consistent with the stronger $\pi$ back-bonding of the $\mathrm{OHC}$ ligand.

Other Ir complexes are likewise accessible. For example, treating DBTOF with $\left[\mathrm{IrCl}_{2} \mathrm{Cp}^{*}\right]_{2}\left(\mathrm{Cp}^{*}=\right.$ pentamethylcyclopentadienyl) in refluxing toluene for 3 days gave orange $\mathrm{OHC}$ Ir(III) complex $3^{\mathrm{O}}$ quantitatively (Scheme 3 , top). NHC complex $3^{\mathrm{N}}$ was obtained analogously in $88 \%$ yield, but SHC complex $3^{\mathrm{S}}$, like $2^{\mathrm{S}}$, could not be obtained, as DBTTF would not dissociate even after prolonged heating at $110{ }^{\circ} \mathrm{C}$.

To access $3^{\mathrm{s}}$, we turned to the deprotonation route using the dithiolium salt. ${ }^{21}$ Slow addition of the strong base potassium hexamethyldisilazide (KHMDS) to a mixture of commercially available benzodithiolium tetrafluoroborate and $\left[\mathrm{IrCl}_{2} \mathrm{Cp}^{*}\right]_{2}$ in THF led indeed to $3^{\mathrm{S}}$ in a remarkably high yield of $80 \%$ 
Scheme 3. Synthesis of the $\operatorname{Ir}\left(\right.$ III) Complexes $3^{\mathrm{N}}, 3^{\mathrm{O}}$, and $3^{\mathrm{S}}$

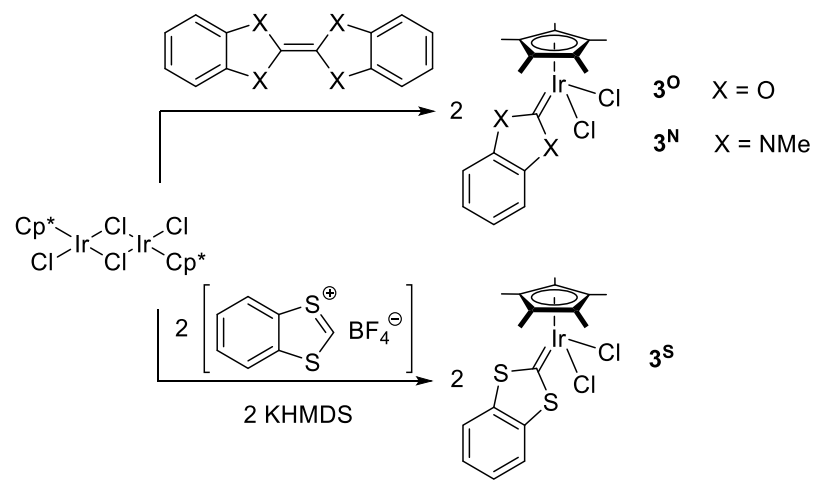

(Scheme 3, bottom); slow addition limits the formation of the carbene dimer. All three $\operatorname{Ir}(\mathrm{III})$ complexes $3^{\mathrm{N}}, 3^{\mathrm{O}}$, and $3^{\mathrm{S}}$ were characterized spectroscopically (see the Supporting Information). The ${ }^{13} \mathrm{C}$ NMR chemical shifts of the carbene carbon atom of $3^{\mathrm{N}}, 3^{\mathrm{O}}$, and $3^{\mathrm{S}}$ at $\delta 170.3,197.9$, and $231.1 \mathrm{ppm}$, respectively, are informative, as they reflect the increased $\pi$ acceptor ability of the carbene ligand on going from $1^{\mathrm{N}}$ to $\mathbf{1}^{\mathrm{O}}$ to $\mathbf{1}^{\mathrm{s}}$, which is in accord with the noted acceptor properties of the carbene ligands. ${ }^{20,22}$

The molecular structures of the complexes obtained by single-crystal X-ray diffraction measurements show surprisingly different spatial orientations (Figure 4$){ }^{23}$ The carbene ligand

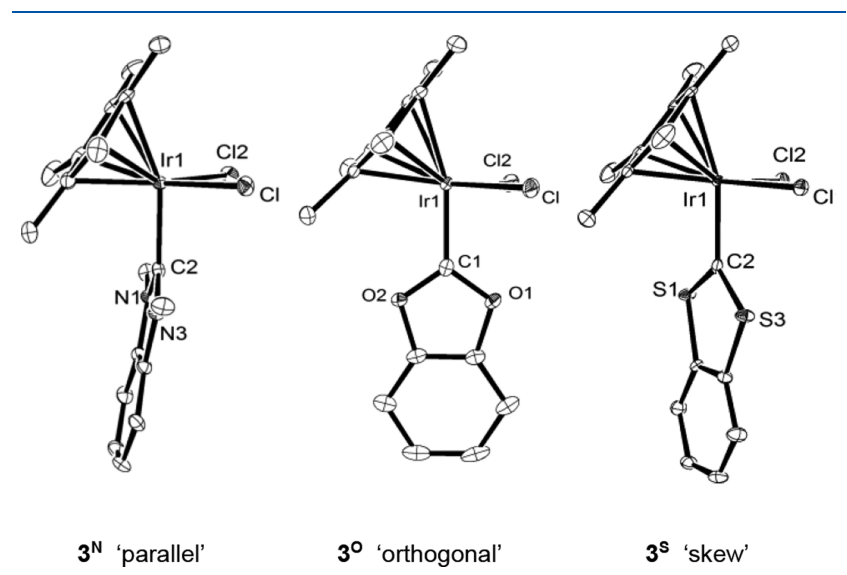

Figure 4. Structures of $3^{\mathrm{N}}$ (left), $3^{\mathrm{O}}$ (middle), and $3^{\mathrm{s}}$ (right) in the crystal state. Ellipsoids are set at $50 \%$ probability; $\mathrm{H}$ atoms are omitted for clarity. Selected bond lengths $(\AA)$ and angles $(\operatorname{deg}): 3^{\mathrm{N}}$, Ir1-C2 2.027(4), N1-C2 1.358(6), N3-C2 1.366(5), N1-C2-N3 105.5(3), C2-Ir1-Cl2 91.50(12), Cl2-Ir1-Cl1 84.20(4); $3^{\mathrm{O}}$, Ir1C1 1.9535(17), O2-C1 1.340(2), O1-C1 1.339(2), O1-C1-O2

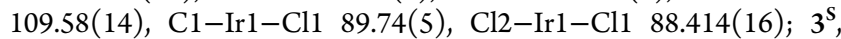
Ir1-C2 1.999(2), S1-C2 1.686(3), S3-C2 1.701(2), S2-C2-S3 114.08(14), C2-Ir1-Cl1 88.89(7), Cl2-Ir1-Cl1 88.95(2).

of $3^{\mathrm{O}}$ is orthogonal to the $\mathrm{Cp}$ * ligand and has a rather short Ir-C bond of $1.9535(17) \AA$, whereas both ligands are aligned ("parallel") in $3^{\mathrm{N}}$, which has a longer $\mathrm{Ir}-\mathrm{C}$ bond of $2.027(4)$ $\AA$. These two structures have approximate $C_{s}$ geometries, while $3^{\mathrm{S}}$ has a "skewed" conformation with a $24^{\circ}$ angle bisecting the planes of the ligands and an Ir-C bond length of 1.999(2) $\AA$ that is intermediate to those of the others. We conclude that the rotation of the carbene by $90^{\circ}$ from $\mathbf{1}^{\mathrm{O}}$ to $\mathbf{1}^{\mathrm{N}}$ is sterically driven, as the $N$-methyl groups would interfere with the $\mathrm{Cp}^{*}$ ring in an orthogonal arrangement. ${ }^{24}$
BP86-3D/TZ2P calculations corroborated this hypothesis, showing "parallel" $3^{\mathrm{N}}$ to be favored over "orthogonal" $3^{\mathrm{N}^{\prime}}$ by a significant $12.5 \mathrm{kcal} \mathrm{mol}^{-1}$; the $\mathrm{N}^{\prime}$ notation reflects the ligand's orthogonality. The two conformational isomers of both $3^{\mathrm{O}}$ and $3^{\mathrm{S}}$ were instead found to be approximately isoenergetic (see the Supporting Information). At this juncture it seemed relevant to examine the nature of the interaction of the carbene ligands $\left(\mathbf{1}^{\mathrm{O}}, \mathbf{1}^{\mathrm{s}}\right.$, and $\left.\mathbf{1}^{\mathrm{N}}\right)$ with $\left[\mathrm{IrCl}_{2} \mathrm{Cp}^{*}\right]$ in the "orthogonal" complexes by using an energy decomposition analysis at the BP86-D3/TZ2P level ( $C_{s}$ symmetry). For comparison, the Ircarbene bond distances of $3^{\mathrm{N}^{\prime}}$ and $3^{\mathrm{S}}$ were fixed to the equilibrium value of $3^{\mathrm{O}}(1.906 \AA)$ to eliminate the effect of steric interactions with the $\mathrm{Cp}^{*}$ ligand. $\sigma$ donation from the carbene lone pair into the empty metal $\mathrm{d}$ orbital dominates the bonding in all three complexes and is stronger for $3^{\mathrm{N}^{\prime}}$ and $3^{\mathrm{S}}$ than for $3^{\mathrm{O}}$ (Figure 5 and Table S3). $\pi$ back-bonding from the

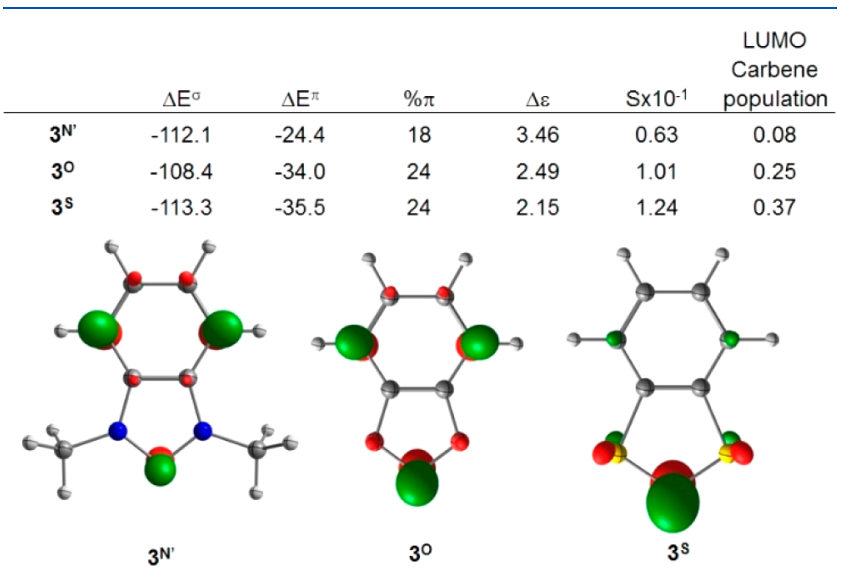

Figure 5. Principal fragment orbitals establishing the back-bonding contribution of the Ir-carbene bond for $3^{\mathrm{N}}, 3^{\mathrm{O}}$, and $3^{\mathrm{S}}$ in the orthogonal conformation (calculated with a $\mathrm{Ir}-\mathrm{C}$ distance of 1.906 $\AA$ ). Below the table are the LUMOs of $3^{\mathrm{N}^{\prime}}$ (left), $3^{\mathrm{O}}$ (middle), and $3^{\mathrm{S}}$ (right) with isocontour values of 0.07 au. Table columns: $\Delta E^{\sigma}$ (symmetrical $\mathrm{a}^{\prime}$ ) and $\Delta E^{\pi}$ (antisymmetrical $\mathrm{a}^{\prime \prime}$ ) are the orbital interaction energy contributions in $\mathrm{kcal} \mathrm{mol}^{-1}$; $\% \pi$ is the relative $\pi$ contribution, $\Delta \varepsilon$ is the HOMO (metal d)-LUMO (carbene $p$ ) energy gap of the fragments in $\mathrm{eV}, \mathrm{S}$ is the orbital overlap, and the population of the carbene LUMO e (see the Supporting Information for details).

metal $\mathrm{d}_{x z}$ orbital into the LUMO of the carbene ( $\mathrm{p}_{\pi}$ orbital) is instead stronger for $3^{\mathrm{O}}(24 \%)$ and $3^{\mathrm{S} \prime}(24 \%)$ than for $3^{\mathrm{N}^{\prime}}$ $(18 \%)$ due the smaller energy gap and better overlap between the fragment orbitals (Figure 5). It appears that NHC $\pi$ backbonding is too modest to compensate the steric interaction in the orthogonal complex, ${ }^{25}$ in concurrence with the experimentally observed and computationally favored parallel conformation of $3^{\mathrm{N}}$. The energy decomposition analysis further confirms the strong $\pi$-accepting property of both the $\mathrm{OHC}$ and SHC ligands, which is evident from the relative energy differences $\Delta \varepsilon$ and the $3^{N^{\prime}}<3^{\mathrm{O}}<3^{\mathrm{S}}$ population of their carbene fragment orbitals.

In an attempt to quantify the net donation of the $\mathbf{1}^{\mathrm{N}}, \mathbf{1}^{\mathrm{O}}$, and $1^{\mathrm{S}}$ ligands to the $\operatorname{Ir}(\mathrm{I})$ center, we turned to the Tolman electronic parameter, which reflects the ligand donor properties in the $\mathrm{CO}$ stretching frequencies of the metal carbonyl group. There are ample such parameters known for NHC TM complexes with excellent linear correlations. The difficulty is, of course, that a CO ligand is required at the Ir center. ${ }^{5,26}$ 
We were able to obtain $\left[\operatorname{IrCl}(\mathrm{CO})_{2} \mathbf{1}^{\mathbf{N}}\right]\left(4^{\mathbf{N}}\right.$; Figure 6), but exposure of $\left[\mathrm{Ir}(\mathrm{Cl})(\mathrm{cod})\left(2^{\mathrm{O}}\right)\right]$ to $\mathrm{CO}$ led, unfortunately, to

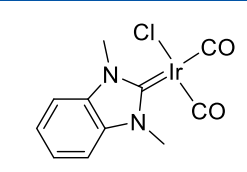

$4^{\mathrm{N}}$

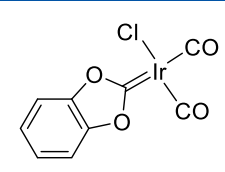

$4^{\circ}$

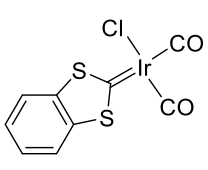

$4^{\mathrm{S}}$
TEP (calc.): $2044 \mathrm{~cm}^{-1} \quad$ TEP (calc.): $2057 \mathrm{~cm}^{-1} \quad$ TEP (calc.): $2049 \mathrm{~cm}^{-1}$ TEP (exp.): $2040 \mathrm{~cm}^{-1}$

Figure 6. Complexes $4^{\mathrm{N}}, 4^{\mathrm{O}}$, and $4^{\mathrm{S}}$ together with their calculated and observed TEPs.

instant decomposition. This observation in itself illustrates the strong acceptor properties of $1^{\circ}$. Since the TEP of $\left(2040 \mathrm{~cm}^{-1}\right.$ for $4^{\mathrm{N}}$ compares well with the computed value of $2044 \mathrm{~cm}^{-1}$ (BP86-D3/TZ2P geometry), we would have expected a larger TEP for $4^{\mathrm{O}}$ on the basis of its calculated value of $2057 \mathrm{~cm}^{-1}$, which is in line with the stronger $\pi$-accepting property of $1^{\mathrm{O}}$. Finally, the computed TEP of $2049 \mathrm{~cm}^{-1}$ for $4^{\mathrm{s}}$ indicates that the net donation of the SHC ligand lies between those of NHC and OHC, which agrees with the noted good $\pi$-acceptor and intermediate $\sigma$-donor capacity of $\mathbf{1}^{\mathrm{S}}$ (see the Supporting Information).

\section{$\mathrm{Cu}, \mathrm{Ag}, \mathrm{AND}$ Au COMPLEXES}

For the synthesis of the OHC and SHC coinage metal(I) complexes, we explored transmetalation, which required access to the unknown silver complexes. Whereas their synthesis by means of alkene dissociation seemed appealing, the reaction of DBTOF or DBTTF with silver(I) salts invariably led to elemental silver, probably due to olefin oxidation akin to tetra$\mathrm{N}$-alkenes and in line with electrochemical studies. ${ }^{18,27}$ Instead, reacting benzodithiolium tetrafluoroborate with a slight excess of silver acetate afforded SHC silver complex $\mathbf{5}^{\mathbf{S}}$ in high (91\%) yield (Scheme 4$).^{28} \mathbf{5}^{\mathrm{S}}$ was fully characterized by NMR

Scheme 4. Synthesis of $5^{S}, 6^{S}, 7^{S}$, and $8^{S}$

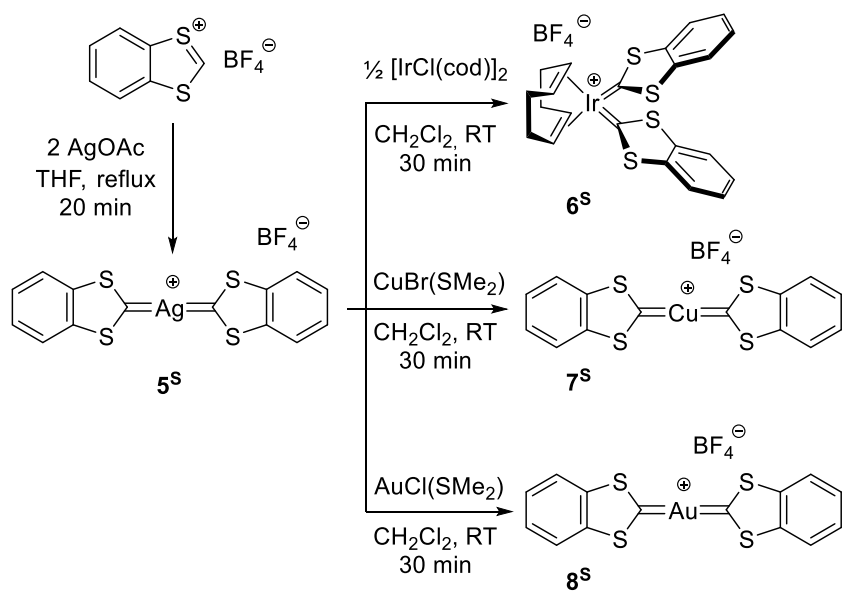

spectroscopy (see the Supporting Information). Its molecular structure, obtained by a single-crystal X-ray structure determination, shows the $\mathrm{BF}_{4}^{-}$anion to be well separated from the cationic complex (the closest $\mathrm{CH} \cdots \mathrm{F}$ contact is 2.366 $\AA$ ). The $\mathrm{Ag}^{+}$complex has approximate $D_{2 h}$ symmetry with two coplanar $1^{\mathrm{s}}$ ligands and a C-Ag-C angle of $176.8(2)^{\circ}$ (Figure 7, left). The $\mathrm{Ag}$-carbene bond lengths of 2.115(7) and

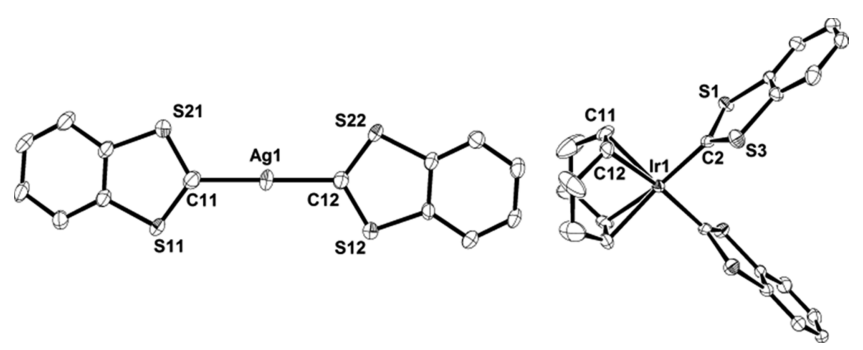

Figure 7. Structures of $5^{\mathrm{S}}$ (left) and $6^{\mathrm{S}}$ (right; only one of two independent molecules in the asymmetric unit is shown) in the crystal state Ellipsoids are set at $50 \%$ probability; counteranions, solvent molecules, and $\mathrm{H}$ atoms are omitted for clarity). Selected bond lengths $(\AA)$ and angles (deg) (those for the second molecule of $6^{\mathrm{S}}$ are given in brackets): $\mathbf{5}^{\mathrm{s}}, \mathrm{Ag1}-\mathrm{C} 112.115(7), \mathrm{Ag1}-\mathrm{C} 12$ 2.103(6), C11S11 1.667(8), C11-S21 1.664(7), C12-S22 1.672(7), C12-S12 1.667(7), C11-Ag-C12 176.8(2), S12-C12-S22 113.7(4), S11C11-S21 114.2(4); $6^{\mathrm{S}}$, Ir1-C2 1.989(2) [1.991(5)], Ir1-C11 $2.210(6)[2.229(5)], \quad \operatorname{Ir} 1-\mathrm{C} 12$ 2.217(6) [2.202(5)], C11-C12 $1.392(9)[1.382(8)], \mathrm{C} 2-\mathrm{S} 1$ 1.692(5) [1.694(5)], C2-S3 1.683(5) $[1.680(6)], \mathrm{C} 2-\mathrm{Ir} 1-\mathrm{C} 2{ }^{\prime} \quad 88.8(3) \quad[88.8(3)], \mathrm{S} 1-\mathrm{C} 2-\mathrm{S} 3$ 114.4(3) $[114.0(3)]$.

2.103(6) $\AA$ are in the upper range of comparable bis-NHCligated $\mathrm{Ag}(\mathrm{I})$ complexes $^{29}$ and reflect weak metal-carbene interactions that are attributed to electronic factors, as the carbene ligands exercise no steric repulsion.

With $5^{5}$ in hand, its potential as a carbene transfer agent could be examined in analogy to the Ag-mediated NHC transfer reactions. ${ }^{30}$ We first pursued iridium complex $2^{\mathrm{S}}$, the missing sulfur analogue of $2^{\mathrm{O}}$ (see Scheme 2), by transferring one SHC ligand from $\mathbf{5}^{\mathbf{s}}$ to $[\mathrm{IrCl}(\operatorname{cod})]_{2}$ but instead obtained bis-SHC complex $6^{\mathrm{S}}$ (Scheme 4, top right) together with an equimolar amount of the unreacted Ir complex; employing 2 equiv of $5^{S}$ gave $6^{S}$ in $73 \%$ yield. The ${ }^{1} \mathrm{H}$ and ${ }^{13} \mathrm{C}$ NMR spectra reveal a highly symmetrical cod ligand and indicate the presence of two SHC ligands, which was confirmed by the molecular structure obtained from a single-crystal X-ray analysis (Figure 7 , right). Whereas the reaction of the $\mathrm{Ag}$ complex $5^{\mathrm{S}}$ with $[\operatorname{IrCl}(\operatorname{cod})]_{2}$ did not yield Ir complex $2^{\mathrm{S}}$ but instead Ir complex $6^{\mathrm{S}}$, the important conclusion is that the $\mathrm{Ag}^{+}$ complex can serve as an SHC transmetallating complex.

To further validate the ability of $\mathbf{5}^{\mathrm{s}}$ to transfer its SHC carbene, we examined its exposure to $\mathrm{Cu}(\mathrm{I})$ and $\mathrm{Au}(\mathrm{I})$ salts. Reacting $5^{\mathrm{S}}$ with an equimolar amount of $\left[\mathrm{CuBr} \cdot \mathrm{SMe}_{2}\right]$ or $\left[\mathrm{AuCl} \cdot \mathrm{SMe}_{2}\right]$ led to the coinage-metal bis-SHC complexes $7^{\mathrm{S}}$ and $8^{\mathrm{s}}$ in $74 \%$ and $88 \%$ yields, respectively (Scheme 4 , right). Both complexes were characterized spectroscopically (see the Supporting Information), as no suitable crystals could be obtained for X-ray crystal structure determinations. The ${ }^{13} \mathrm{C}$ NMR chemical shifts of the carbene carbon atoms of $7^{\mathrm{S}}$ and $\mathbf{8}^{\mathrm{S}}$ at $\delta 235.4$ and $232.0 \mathrm{ppm}$, respectively, compare well with $\delta$ 231.1 for the Ir complex $3^{\mathrm{S}}$ and reflect the strong $\pi$-acceptor ability of the SHC carbene ligand.

The bonding nature of the coinage metal complexes $5^{\mathrm{S}}, 7^{\mathrm{S}}$, and $\mathbf{8}^{\mathrm{S}}$ was assessed at the BP86/TZ2P level using $D_{2 h^{-}}$ optimized geometries. The lengths of the metal-carbene bonds $\left(5^{\mathrm{S}}, 2.071 \AA ; 7^{\mathrm{S}}, 1.869 \AA ; \mathbf{8}^{\mathrm{S}}, 2.020 \AA\right)$ and their strengths $(\mathrm{Ag}<\mathrm{Cu}<\mathrm{Au})$, as deduced from an energy decomposition analysis (Table 1), follow the commonly observed trends. ${ }^{31}$ Silver complexes have the weakest bond, which concurs with their use as a transmetalation reagent. The bonding to the $\mathrm{d}^{10}$ group 11 metal cations are governed by electrostatic interactions ${ }^{32}$ and are comparable to those of the 
Table 1. Energy Decomposition Analyses and Bond Dissociation Energies (in kcal mol ${ }^{-1}$ ) for the Coinage-Metal $(\mathrm{SHC})_{2}$ Complexes $5^{S}, 7^{S}$, and $8^{S}$ and for the Gold NHC and OHC Complexes $\left[\mathrm{Au}\left(1^{\mathrm{N}}\right)_{2}\right]^{+}\left(8^{\mathrm{N}}\right)$ and $\left[\mathrm{Au}\left(1^{\mathrm{O}}\right)_{2}\right]^{+}\left(8^{\mathrm{O}}\right)$

$\begin{array}{llllll} & \mathbf{5}^{\mathrm{S}}(\mathrm{Ag}) & \mathbf{7}^{\mathrm{S}}(\mathrm{Cu}) & \mathbf{8}^{\mathrm{S}}(\mathrm{Au}) & \mathbf{8}^{\mathrm{N}}(\mathrm{Au}) & \mathbf{8}^{\mathrm{O}}(\mathrm{Au}) \\ d_{\mathrm{M}-\text { carbene }}(\AA) & 2.071 & 1.869 & 2.020 & 2.030 & 2.011 \\ \Delta E_{\sigma}\left(\mathrm{kcal} \mathrm{mol}^{-1}\right) & -84.7 & -96.6 & -145.1 & -143.2 & -141.1 \\ \Delta E_{\pi}\left(\mathrm{kcal} \mathrm{mol}^{-1}\right) & -23.1 & -34.1 & -32.3 & -31.1 & -32.0 \\ \Delta E_{\text {bond }}\left(\mathrm{kcal} \mathrm{mol}^{-1}\right) & -152.2 & -193.7 & -215.0 & -238.9 & -205.4\end{array}$

$\left[\mathrm{M}(\mathrm{CAAC})_{2}\right]^{+}(\mathrm{M}=\mathrm{Cu}, \mathrm{Ag}, \mathrm{Au})$ complexes, which have been studied by Bertrand and Frenking ${ }^{33}$ using the EDA-NOCV scheme and by Weinhold within the NBO model. ${ }^{34}$ The main orbital contribution for the SHC complexes $\left(5^{\mathrm{S}}(\mathrm{Ag}), 7^{\mathrm{S}}(\mathrm{Cu})\right.$, $\mathbf{8}^{\mathrm{S}}(\mathrm{Au})$; Table 1$)$ is due to $\sigma$ bonding from the carbene lone pair to the coinage-metal cations and is the strongest for $\mathrm{Au}$ due to the relativistic effect on the atomic orbitals, where the valence $s$ and $p$ orbitals are contracted and the $d$ and $f$ orbitals expanded. ${ }^{32}$ However, the more distinguishing feature is the sizable $\pi$ back-bonding of the SHC and OHC ligands ( $\sim 32$ $\mathrm{kcal} / \mathrm{mol}$; Table 1$)$, as it is about twice that of CAAC. ${ }^{32}$ In comparison to the NHC ligand, the SHC and OHC ligands both bind less strongly to $\mathrm{Cu}(\mathrm{I}), \mathrm{Ag}(\mathrm{I})$, and $\mathrm{Au}(\mathrm{I}$ ) (see Table 1 for the $\mathrm{Au}(\mathrm{I})$ complexes and the Supporting Information for a detailed bond energy analysis of all).

\section{CONCLUSIONS}

In summary, we report on the convenient syntheses of new $\mathrm{OHC}$ and SHC transition-metal complexes by (1) dissociation of a suitable olefin, (2) deprotonation of a precursor salt, or (3) transmetalation from a precursor Ag complex. The hitherto neglected OHCs and SHCs differ both electronically and sterically from the classical NHCs and thereby extend the panoply of available carbene ligands. Their strong $\pi$-accepting properties can be beneficial in synthetic and catalytic applications. Especially notable is the capability of $5^{\mathrm{s}}$ to transfer the SHC ligand, allowing for facile access to a much wider range of carbene complexes. The applicability of the new benzannulated heterocyclic carbenes OHC $\mathbf{1}^{\mathrm{O}}$ and SHC $\mathbf{1}^{\mathrm{s}}$ is a target for further study.

\section{EXPERIMENTAL SECTION}

Materials and Methods. All reactions and manipulations were carried out under an atmosphere of dry nitrogen using standard Schlenk techniques or in a glovebox, unless otherwise stated. Dry, oxygen-free solvents were employed. Melting points were determined with samples in nitrogen-filled, sealed capillaries using a Büchi M-565 Melting Point apparatus and are uncorrected. Solution ${ }^{1} \mathrm{H},{ }^{13} \mathrm{C},{ }^{11} \mathrm{~B}$, ${ }^{19} \mathrm{~F}$, and ${ }^{77} \mathrm{Se}$ NMR spectra were recorded on Bruker Avance 250 $\left({ }^{19} \mathrm{~F}\right), 400\left({ }^{1} \mathrm{H},{ }^{13} \mathrm{C},{ }^{19} \mathrm{~B},{ }^{77} \mathrm{Se}\right)$ and $500\left({ }^{1} \mathrm{H},{ }^{13} \mathrm{C}\right)$ spectrometers at $298 \mathrm{~K}$, unless otherwise stated. Chemical shifts $(\delta)$ are expressed with a positive sign, in parts per million. ${ }^{1} \mathrm{H}$ and ${ }^{13} \mathrm{C}$ chemical shifts reported were referenced internally to residual protio $(1 \mathrm{H})$ or deuterio $\left({ }^{13} \mathrm{C}\right)$ solvent, ${ }^{35}$ while ${ }^{11} \mathrm{~B},{ }^{19} \mathrm{~F}$, and ${ }^{77} \mathrm{Se}$ chemical shifts are relative to $\mathrm{BF}_{3} \cdot \mathrm{Et}_{2} \mathrm{O}, \mathrm{CFCl}_{3}$, and $0.25 \mathrm{~mol} / \mathrm{L} \mathrm{KSeCN}$ (aqueous, -329 $\mathrm{ppm}$ ) external references, respectively. The following abbreviations and their combinations are used: br, broad; s, singlet; d, doublet; $t$, triplet; q, quartet, $\mathrm{m}$, multiplet. The ${ }^{1} \mathrm{H}$ and ${ }^{13} \mathrm{C}$ resonance signals were attributed by means of $2 \mathrm{D}$ HSQC and HMBC experiments when necessary. Infrared spectra were recorded with a Shimadzu FTIR $8400 S$ spectrometer. Vibrational bands $(\nu)$ are expressed in $\mathrm{cm}^{-1}$. Electrospray ionization (ESI) mass spectra were recorded on a Bruker Daltonics microTOF apparatus in positive ion mode (capillary potential of $4500 \mathrm{~V})$. Benzo-1,3-dioxole-2-selone $\left(\mathbf{1}^{\mathrm{O}}-\mathrm{Se}\right),{ }^{17}$ dibenzo- tetraoxafulvalene, ${ }^{17}$ pentamethylcyclopentadienyl iridium(III) chloride dimer $\left(\left[\mathrm{IrCl}_{2} \mathrm{Cp} *\right]_{2}\right),{ }^{36}$ and bis(1,3-dimethylbenzimidazolidin-2ylidene $)^{37}$ were prepared according to reported procedures. All other starting materials were purchased from commercial vendors and used without further purification.

$1^{\mathrm{N}}$-Se. This compound was prepared according to modified reported procedures. ${ }^{38} \mathrm{NaHMDS}$ (363 $\mathrm{mg}, 1.98 \mathrm{mmol}, 1.1$ equiv) in $\mathrm{Et}_{2} \mathrm{O}(10 \mathrm{~mL})$ was added via cannula to a dispersion of 1,3-dimethyl$1 \mathrm{H}$-benzimidazolium iodide (493 $\mathrm{mg}, 1.8 \mathrm{mmol}, 1.0$ equiv) and $\mathrm{Se}$ powder $\left(710 \mathrm{mg}, 9 \mathrm{mmol}, 5.0\right.$ equiv) in $\mathrm{Et}_{2} \mathrm{O}(15 \mathrm{~mL})$ at $-78{ }^{\circ} \mathrm{C}$. The cannula was rinsed with additional $\mathrm{Et}_{2} \mathrm{O}(5 \mathrm{~mL})$. After the reaction mixture was stirred for $20 \mathrm{~min}$ at $-78{ }^{\circ} \mathrm{C}$, the cold bath was removed and the suspension was stirred for $12 \mathrm{~h}$ and warmed to room temperature. The reaction mixture was filtered over a pad of Celite (3 $\mathrm{cm})$ and silica gel $(3 \mathrm{~cm})$ on a filter frit. The frit was rinsed with additional $\mathrm{Et}_{2} \mathrm{O}(20 \mathrm{~mL})$. Volatiles were removed in vacuo. The resulting yellow residue was recrystallized from $\mathrm{Et}_{2} \mathrm{O}$ to give $\mathbf{1}^{\mathrm{N}}$-Se as yellow crystals. Yield: $135 \mathrm{mg}(33 \%)$. Mp: $174-176{ }^{\circ} \mathrm{C} .{ }^{1} \mathrm{H}$ NMR $\left(400 \mathrm{MHz}, \mathrm{CDCl}_{3}\right): \delta 7.57\left(\mathrm{~s}, 4 \mathrm{H}, \mathrm{H}_{\mathrm{Ar}}\right), 3.89\left(\mathrm{~s}, 6 \mathrm{H}, \mathrm{H}_{\mathrm{CH} 3}\right) .{ }^{13} \mathrm{C}\left\{{ }^{1} \mathrm{H}\right\}$ $\operatorname{NMR}\left(100 \mathrm{MHz}, \mathrm{CDCl}_{3}\right) \delta 166.9\left(\mathrm{~s}, \mathrm{C}_{\mathrm{C}=\mathrm{Se}}\right), 133.5\left(\mathrm{~s}, \mathrm{C}_{\mathrm{ArN}}\right), 123.8$ $\left(\mathrm{s}, \mathrm{C}_{\mathrm{ArH}}\right), 109.6\left(\mathrm{~s}, \mathrm{C}_{\mathrm{ArH}}\right), 33.4\left(\mathrm{~s}, \mathrm{C}_{\mathrm{CH}}\right) .{ }^{77} \mathrm{Se}\left\{{ }^{1} \mathrm{H}\right\} \mathrm{NMR}(76 \mathrm{MHz}$, $\left.\left(\mathrm{CD}_{3}\right)_{2} \mathrm{CO}\right): \delta 80.0$ (s). IR (ATR): $\nu$ 3094, 3043, 2962, 2085, 2004, 1454, 1383, 1333, 733. HRMS (ESI+): calcd for $[\mathrm{M}+\mathrm{H}]^{+}=$ $\mathrm{C}_{9} \mathrm{H}_{11} \mathrm{~N}_{2} \mathrm{Se}^{+}, 227.0082$; found, 227.0074 .

$1^{\mathrm{S}}$-Se. NaHMDS (363 mg, $1.98 \mathrm{mmol}, 1.1$ equiv) in $\mathrm{Et}_{2} \mathrm{O}(15 \mathrm{~mL})$ was added via a cannula very slowly (ca. $30 \mathrm{~min}$ ) to a dispersion of 1,3-dimethyl-1H-benzimidazolium iodide (493 mg, $1.8 \mathrm{mmol}, 1.0$ equiv) and Se powder $\left(710 \mathrm{mg}, 9 \mathrm{mmol}, 5.0\right.$ equiv) in $\mathrm{Et}_{2} \mathrm{O}(15 \mathrm{~mL})$ at ambient temperature. The cannula was rinsed with additional $\mathrm{Et}_{2} \mathrm{O}$ $(2 \mathrm{~mL})$. The gray suspension was stirred for $12 \mathrm{~h}$. The reaction mixture was filtered over a pad of Celite $(3 \mathrm{~cm})$ and silica gel $(3 \mathrm{~cm})$ on a filter frit. The frit was rinsed with additional $\mathrm{Et}_{2} \mathrm{O}(50 \mathrm{~mL})$. Volatiles were removed in vacuo. The resulting orange residue was purified by column chromatography (silica gel, cyclohexane, $R_{\mathrm{f}}=$ $0.13)$ to give $1^{\mathrm{s}}$-Se as an orange crystalline powder. Yield: $37 \mathrm{mg}$ (9\%). The predominant byproduct of this reaction is dibenzotetrathiafulvalene. $1^{\mathrm{S}}$-Se decomposes slowly on the column during the chromatographic workup and when it is kept in solution. Mp: 219$220{ }^{\circ} \mathrm{C}$ dec (lit. $\left.{ }^{39} \mathrm{mp} 214-216{ }^{\circ} \mathrm{C}\right) .{ }^{1} \mathrm{H}$ NMR $\left(400 \mathrm{MHz}, \mathrm{CD}_{2} \mathrm{Cl}_{2}\right): \delta$ $7.61\left(\mathrm{~m}, 2 \mathrm{H}, \mathrm{H}_{\mathrm{Ar}}\right), 7.35\left(\mathrm{~m}, 2 \mathrm{H}, \mathrm{H}_{\mathrm{Ar}}\right) \cdot{ }^{13} \mathrm{C}\left\{{ }^{1} \mathrm{H}\right\} \mathrm{NMR}(100 \mathrm{MHz}$, $\left.\mathrm{CD}_{2} \mathrm{Cl}_{2}\right) \delta 205.3\left(\mathrm{~s}, \mathrm{C}_{\mathrm{C}=\mathrm{Se}}\right), 145.3\left(\mathrm{~s}, \mathrm{C}_{\mathrm{ArS}}\right), 127.9\left(\mathrm{~s}, \mathrm{C}_{\mathrm{ArH}}\right), 121.9(\mathrm{~s}$, $\left.\mathrm{C}_{\mathrm{ArH}}\right) .{ }^{77} \mathrm{Se}\left\{{ }^{1} \mathrm{H}\right\}$ NMR $\left(76 \mathrm{MHz},\left(\mathrm{CD}_{3}\right)_{2} \mathrm{CO}\right): \delta 1017.2$ (s). IR (ATR): $\nu$ 3047, 2955, 2922, 2853, 1431, 1261, 933, 906. HRMS (ESI + ): calcd for $[\mathrm{M}+\mathrm{H}-\mathrm{Se}]^{+}=\mathrm{C}_{7} \mathrm{H}_{5} \mathrm{~S}_{2}{ }^{+}, 152.9827$; found, 152.9828 .

$2^{\mathrm{N}}$. 1,3-Dimethyl- $1 \mathrm{H}$-benzimidazolium iodide $(274.1 \mathrm{mg}, 1.0$ mmol, 1.0 equiv) and $\mathrm{Ag}_{2} \mathrm{O}$ (115.9 mg, $0.5 \mathrm{mmol}, 0.5$ equiv) were transferred into a Schlenk flask, suspended in dichloromethane (5 $\mathrm{mL}$ ), and stirred for $60 \mathrm{~min}$ at ambient temperature with exclusion of light. The iridium dimer complex $\left[\mathrm{Ir}_{2} \mathrm{Cl}_{2}(\mathrm{cod})_{2}\right](336.0 \mathrm{mg}, 0.5$ mmol, 0.5 equiv) was added under a positive nitrogen flow. The yellow suspension was stirred for $4.5 \mathrm{~h}$ with exclusion of light and then filtered over a pad of Celite to give a clear dark yellow solution. Volatiles were removed in vacuo. The orange residue was purified in air by column chromatography (silica gel, eluent dichloromethane, $R_{\mathrm{f}}$ $=0.37$ ) to give $2^{\mathrm{N}}$ as a bright yellow crystalline solid. Crystals suitable for X-ray crystallography were grown at $4{ }^{\circ} \mathrm{C}$ by vapor diffusion of diethyl ether into a concentrated solution of $2^{\mathrm{N}}$ in dichloromethane. Yield: $448 \mathrm{mg}$ (93\%). Mp: $188-191{ }^{\circ} \mathrm{C}$ dec. ${ }^{1} \mathrm{H}$ NMR (400 MHz, $\left.\mathrm{CDCl}_{3}\right): \delta 7.31-7.23\left(\mathrm{~m}, 4 \mathrm{H}, \mathrm{H}_{4}\right.$ and $\left.\mathrm{H}_{5}\right), 4.74\left(\mathrm{~m}, 2 \mathrm{H}, \mathrm{H}_{6}\right.$ or $\left.\mathrm{H}_{9}\right)$, $4.17\left(\mathrm{~s}, 6 \mathrm{H}, \mathrm{H}_{2}\right), 2.98\left(\mathrm{~m}, 2 \mathrm{H}, \mathrm{H}_{6}\right.$ or $\left.\mathrm{H}_{9}\right), 2.30\left(\mathrm{~m}, 4 \mathrm{H}, \mathrm{H}_{7}\right.$ or $\left.\mathrm{H}_{8}\right)$, $1.75\left(\mathrm{~m}, 4 \mathrm{H}, \mathrm{H}_{7}\right.$ or $\left.\mathrm{H}_{8}\right) .{ }^{13} \mathrm{C}\left\{{ }^{1} \mathrm{H}\right\} \mathrm{NMR}\left(100 \mathrm{MHz}, \mathrm{CDCl}_{3}\right): \delta 192.0$ $\left(\mathrm{s}, \mathrm{C}_{1}\right), 135.6\left(\mathrm{~s}, \mathrm{C}_{3}\right), 122.7\left(\mathrm{~s}, \mathrm{C}_{4}\right.$ or $\left.\mathrm{C}_{5}\right), 109.6\left(\mathrm{~s}, \mathrm{C}_{4}\right.$ or $\left.\mathrm{C}_{5}\right), 87.0(\mathrm{~s}$, $\mathrm{C}_{6}$ or $\left.\mathrm{C}_{9}\right), 52.3\left(\mathrm{~s}, \mathrm{C}_{6}\right.$ or $\left.\mathrm{C}_{9}\right), 34.4\left(\mathrm{~s}, \mathrm{C}_{2}\right), 33.7\left(\mathrm{~s}, \mathrm{C}_{7}\right.$ or $\left.\mathrm{C}_{8}\right), 29.6(\mathrm{~s}$, $\mathrm{C}_{7}$ or $\mathrm{C}_{8}$ ); IR (ATR): $\nu$ 3026, 2928, 2878, 2827, 1489, 1436, 1342, 1094, 754, 744, 565. HRMS (ESI+): calcd for $[\mathrm{M}-\mathrm{Cl}]^{+}=$ $\mathrm{C}_{17} \mathrm{H}_{22} \mathrm{~N}_{2} \mathrm{Ir}^{+}$, 447.1407; found, 447.1392.

$2^{\mathrm{O}}$. The iridium dimer complex $\left[\mathrm{Ir}_{2} \mathrm{Cl}_{2}(\operatorname{cod})_{2}\right](357 \mathrm{mg}, 0.53$ mmol, 1.0 equiv) and dibenzotetraoxafulvalene $(166 \mathrm{mg}, 0.69 \mathrm{mmol}$, 1.3 equiv) were transferred into a Schlenk flask and solubilized in toluene $(6 \mathrm{~mL})$. The mixture was stirred at room temperature for 4 
days. Over time, the media changed gradually from orange to brown. Volatiles were removed in vacuo, and the residue was washed with diethyl ether $(8 \times 5 \mathrm{~mL})$ to remove starting material and byproducts; the product is also slightly soluble in diethyl ether. The remaining redorange solid was dried under vacuum to give $2^{\circ}$. Yield: $280 \mathrm{mg}$ (58\%). Crystals suitable for X-ray crystallography were grown at room temperature by vapor diffusion of diethyl ether into a solution of $2^{\mathrm{O}}$ in dichloromethane. The compound decomposes under nitrogen and only slowly (over days) in solution at room temperature, as indicated by formation of a black insoluble residue. Mp: $115-117{ }^{\circ} \mathrm{C} \mathrm{dec} .{ }^{1} \mathrm{H}$ NMR $\left(400 \mathrm{MHz}, \mathrm{CDCl}_{3}\right): \delta 7.55\left(\mathrm{~m}, 2 \mathrm{H}, \mathrm{H}_{3}\right.$ or $\left.\mathrm{H}_{4}\right), 7.40(\mathrm{~m}, 2 \mathrm{H}$, $\mathrm{H}_{3}$ or $\left.\mathrm{H}_{4}\right), 5.53\left(\mathrm{~m}, 2 \mathrm{H}, \mathrm{H}_{8}\right), 3.52\left(\mathrm{~m}, 2 \mathrm{H}, \mathrm{H}_{5}\right), 2.60\left(\mathrm{~m}, 8 \mathrm{H}, \mathrm{H}_{6}\right.$ and $\left.\mathrm{H}_{7}\right) .{ }^{13} \mathrm{C}\left\{{ }^{1} \mathrm{H}\right\}$ NMR $\left(100 \mathrm{MHz}, \mathrm{CDCl}_{3}\right) \delta 209.2\left(\mathrm{~s}, \mathrm{C}_{1}\right), 146.7(\mathrm{~s}$, $\left.\mathrm{C}_{2}\right), 126.5\left(\mathrm{~s}, \mathrm{C}_{3}\right.$ or $\left.\mathrm{C}_{4}\right), 111.8\left(\mathrm{~s}, \mathrm{C}_{3}\right.$ or $\left.\mathrm{C}_{4}\right), 104.7\left(\mathrm{~s}, \mathrm{C}_{8}\right), 56.1(\mathrm{~s}$, $\left.\mathrm{C}_{5}\right), 33.6\left(\mathrm{~s}, \mathrm{C}_{6}\right.$ or $\left.\mathrm{C}_{7}\right), 29.4\left(\mathrm{~s}, \mathrm{C}_{6}\right.$ or $\left.\mathrm{C}_{7}\right)$. IR (ATR): $\nu$ 3097, 3057, 3018, 2952, 2880, 2833, 1466, 1333, 1194, 1049, 746. HRMS (ESI+): calcd for $[\mathrm{M}-\mathrm{Cl}]^{+}=\mathrm{C}_{15} \mathrm{H}_{16} \mathrm{O}_{2} \mathrm{Ir}^{+}, 421.0774$; found, 421.0785 .

$3^{\mathrm{N}}$. A solution of bis(1,3-dimethylbenzimidazolidin-2-ylidene) (29.2 $\mathrm{mg}, 0.10 \mathrm{mmol}, 1.0$ equiv) in toluene $(1 \mathrm{~mL})$ was added to a solution of $\left[\mathrm{IrCl}_{2} \mathrm{Cp}^{*}\right]_{2}(79.7 \mathrm{mg}, 0.10 \mathrm{mmol}, 1.0$ equiv) in toluene (1 $\mathrm{mL})$. The reaction mixture was stirred for $4 \mathrm{~h}$ at $100{ }^{\circ} \mathrm{C}$ and then for 2 days at room temperature in order to ensure full conversion and limit thermal decomposition. The resulting yellow precipitate was isolated by filtration, washed with diethyl ether $(3 \times 2 \mathrm{~mL})$, and dried under vacuum to give $3^{\mathrm{N}}$. Yield: $95 \mathrm{mg}(88 \%)$. Crystals suitable for Xray crystallography were grown at room temperature by vapor diffusion of pentane into a solution of $3^{\mathbf{N}}$ in dichloromethane. Mp: $334{ }^{\circ} \mathrm{C} .{ }^{1} \mathrm{H}$ NMR $\left(400 \mathrm{MHz}, \mathrm{CDCl}_{3}\right): \delta 7.37\left(\mathrm{~m}, 2 \mathrm{H}, \mathrm{H}_{3}\right.$ or $\left.\mathrm{H}_{4}\right), 7.30$ $\left(\mathrm{m}, 2 \mathrm{H}, \mathrm{H}_{3}\right.$ or $\left.\mathrm{H}_{4}\right), 4.17$ (s, $\left.6 \mathrm{H}, \mathrm{H}_{\mathrm{N}-\mathrm{CH} 3}\right), 1.68\left(\mathrm{~s}, 15 \mathrm{H}, \mathrm{H}_{\mathrm{Cp}^{*}-\mathrm{CH} 3}\right)$. ${ }^{13} \mathrm{C}\left\{{ }^{1} \mathrm{H}\right\} \operatorname{NMR}\left(100 \mathrm{MHz}, \mathrm{CDCl}_{3}\right) \delta 170.25\left(\mathrm{~s}, \mathrm{C}_{1}\right), 135.87\left(\mathrm{~s}, \mathrm{C}_{2}\right)$, $123.49\left(\mathrm{~s}, \mathrm{C}_{3}\right.$ or $\left.\mathrm{C}_{4}\right), 110.35\left(\mathrm{~s}, \mathrm{C}_{3}\right.$ or $\left.\mathrm{C}_{4}\right), 89.61\left(\mathrm{~s}, \mathrm{C}_{\mathrm{Cp}^{*}}\right), 35.60(\mathrm{~s}$, $\left.\mathrm{C}_{\mathrm{N}-\mathrm{CH} 3}\right), 9.35$ (s, $\left.\mathrm{C}_{\mathrm{Cp}^{*}-\mathrm{CH} 3}\right)$. IR (ATR): $\nu$ 1444, 1375, 1344, 1093, 767. HRMS (ESI+): calcd for $[\mathrm{M}-\mathrm{Cl}]^{+}=\mathrm{C}_{19} \mathrm{H}_{25} \mathrm{ClN}_{2} \mathrm{Ir}^{+}, 509.1330$; found, 509.1330 .

$3^{\circ}$. The iridium dimer complex $\left[\mathrm{IrCl}_{2} \mathrm{Cp}^{*}\right]_{2}(199 \mathrm{mg}, 0.25 \mathrm{mmol}$, 1.0 equiv) and dibenzotetraoxafulvalene (60 $\mathrm{mg}, 0.25 \mathrm{mmol}, 1$ equiv) were transferred into a pressurizable Schlenk flask (featuring a screw cap) and dispersed in toluene $(6 \mathrm{~mL})$. The mixture was heated at 110 ${ }^{\circ} \mathrm{C}$ with vigorous stirring. Over time, the media changed from red to yellow. After $64 \mathrm{~h}$, the mixture was cooled to room temperature. The yellow-orange residue was isolated by cannula filtration, washed with $\mathrm{Et}_{2} \mathrm{O}(3 \times 3 \mathrm{~mL})$, and subsequently dried in vacuo. Yield: $258 \mathrm{mg}$ (quantitative). Crystals suitable for X-ray crystallography were grown at room temperature by vapor diffusion of pentane into a concentrated solution of $3^{\mathrm{O}}$ in dichloromethane. Mp: $139-204{ }^{\circ} \mathrm{C}$ dec. ${ }^{1} \mathrm{H}$ NMR (400 MHz, $\left.\mathrm{CDCl}_{3}\right): \delta 7.65\left(\mathrm{~m}, 2 \mathrm{H}, \mathrm{H}_{\mathrm{ar}}\right), 7.43(\mathrm{~m}, 2 \mathrm{H}$, $\left.\mathrm{H}_{\mathrm{ar}}\right), 1.84\left(\mathrm{~s}, 15 \mathrm{H}, \mathrm{H}_{\mathrm{CH} 3-\mathrm{Cp} *}\right) .{ }^{13} \mathrm{C}\left\{{ }^{1} \mathrm{H}\right\} \mathrm{NMR}\left(100 \mathrm{MHz} \mathrm{CDCl}_{3}\right): \delta$ $197.9\left(\mathrm{~s}, \mathrm{C}_{1}\right), 147.3\left(\mathrm{~s}, \mathrm{C}_{2}\right), 126.8\left(\mathrm{~s}, \mathrm{C}_{4}\right), 111.9\left(\mathrm{~s}, \mathrm{C}_{3}\right), 95.8(\mathrm{~s}$, $\left.\mathrm{C}_{\mathrm{Ar}^{-\mathrm{Cp}^{*}}}\right), 9.2\left(\mathrm{~s}, \mathrm{C}_{\mathrm{CH} 3-\mathrm{Cp}^{*}}\right)$. IR (ATR): $\nu$ 3086, 3058, 2916, 1458, $1199,793,758$. HRMS (ESI+): calcd for $[\mathrm{M}-\mathrm{Cl}]^{+}=\mathrm{C}_{17} \mathrm{H}_{19} \mathrm{ClIrO}_{2}^{+}$, 483.0703; found, 483.0689 .

$3^{\mathrm{S}}$. To a solution of the iridium dimer complex $\left[\mathrm{IrCl}_{2} \mathrm{Cp} *\right]_{2}(150$ $\mathrm{mg}, 0.19 \mathrm{mmol}, 1.0$ equiv) and benzodithiolium tetrafluoroborate (180.8 mg, $0.75 \mathrm{mmol}, 4.0$ equiv) in dichloromethane $(15 \mathrm{~mL})$ was slowly added at $0{ }^{\circ} \mathrm{C}$ a solution of KHMDS $(150.2 \mathrm{mg}, 0.75 \mathrm{mmol}$, 4.0 equiv) in tetrahydrofuran $(15 \mathrm{~mL})$ by means of a syringe pump over $160 \mathrm{~min}$. Slow addition of the thiazolium salt is mandatory to avoid extensive formation of the corresponding carbene dimer. After the addition was finished, the mixture was warmed to room temperature, volatiles were removed under vacuum, and the residue was washed with diethyl ether $(4 \times 5 \mathrm{~mL})$ and benzene $(2 \times 4 \mathrm{~mL})$ and dried under vacuum to yield $3^{\mathrm{S}}$ as a yellow-orange powder. Yield: $164 \mathrm{mg}(80 \%)$. Crystals suitable for X-ray crystallography were grown at room temperature by vapor diffusion of pentane into a concentrated solution of $3^{\mathrm{S}}$ in dichloromethane. Mp: $>195-265{ }^{\circ} \mathrm{C}$ dec. ${ }^{1} \mathrm{H}$ NMR $\left(400 \mathrm{MHz}, \mathrm{CD}_{2} \mathrm{Cl}_{2}\right): \delta 8.11\left(\mathrm{~m}, 2 \mathrm{H}, \mathrm{H}_{\mathrm{ar}}\right), 7.56(\mathrm{~m}, 2 \mathrm{H}$, $\left.\mathrm{H}_{\mathrm{ar}}\right), 1.68\left(\mathrm{~s}, 15 \mathrm{H}, \mathrm{H}_{\mathrm{CH} 3-\mathrm{Cp}^{*}}\right) .{ }^{13} \mathrm{C}\left\{{ }^{1} \mathrm{H}\right\} \mathrm{NMR}\left(100 \mathrm{MHz}, \mathrm{CDCl}_{3}\right): \delta$ $231.1\left(\mathrm{~s}, \mathrm{C}_{1}\right), 150.1\left(\mathrm{~s}, \mathrm{C}_{2}\right), 127.5\left(\mathrm{~s}, \mathrm{C}_{4}\right), 123.3\left(\mathrm{~s}, \mathrm{C}_{3}\right), 92.8(\mathrm{~s}$, $\left.\mathrm{C}_{\mathrm{Ar}-\mathrm{Cp}^{*}}\right), 8.7$ (s, $\left.\mathrm{C}_{\mathrm{CH} 3-\mathrm{Cp}^{*}}\right)$. IR (ATR): $\nu$ 3061, 2983, 2964, 2918, $1751,1491,1435,1421,1400,1373,1027,939,875,777$. HRMS
(ESI+): calcd for $[\mathrm{M}-\mathrm{Cl}]^{+}=\mathrm{C}_{17} \mathrm{H}_{19} \mathrm{ClIrS}_{2}{ }^{+}, 515.0230$; found, 515.0205

$4^{\mathrm{N}}$. Iridium $\mathrm{NHC}(\mathrm{COD})$ complex $2^{\mathrm{N}}(55 \mathrm{mg}, 0.11 \mathrm{mmol}, 1.0$ equiv) was transferred into a Schlenk flask and solubilized in dichloromethane $(25 \mathrm{~mL})$. CO gas was bubbled through the solution for $10 \mathrm{~min}$. Volatiles were removed in vacuo. The yellow residue was washed with pentane $(3 \times 2 \mathrm{~mL})$ and dried under vacuum to give $4^{\mathrm{N}}$ as a microcrystalline yellow powder. Yield: $43 \mathrm{mg}$ (91\%). Mp: $158-$ $159{ }^{\circ} \mathrm{C}$ dec. ${ }^{1} \mathrm{H} \operatorname{NMR}\left(500 \mathrm{MHz}, \mathrm{CD}_{2} \mathrm{Cl}_{2}\right): \delta 7.49\left(\mathrm{~m}, 2 \mathrm{H}, \mathrm{H}_{4}\right.$ or $\left.\mathrm{H}_{5}\right)$, $7.43\left(\mathrm{~m}, 2 \mathrm{H}, \mathrm{H}_{4}\right.$ or $\left.\mathrm{H}_{5}\right), 4.10\left(\mathrm{~s}, 6 \mathrm{H}, \mathrm{H}_{2}\right) .{ }^{13} \mathrm{C}\left\{{ }^{1} \mathrm{H}\right\}$ NMR $(126 \mathrm{MHz}$, $\left.\mathrm{CD}_{2} \mathrm{Cl}_{2}\right) \delta 183.4\left(\mathrm{~s}, \mathrm{C}_{1}\right), 182.3$ (s, $\left.\mathrm{CO}_{\text {trans }}\right), 168.5\left(\mathrm{~s}, \mathrm{CO}_{\text {cis }}\right), 135.1$ (s, $\left.\mathrm{C}_{3}\right), 124.4\left(\mathrm{~s}, \mathrm{C}_{4}\right.$ or $\left.\mathrm{C}_{5}\right), 111.1\left(\mathrm{~s}, \mathrm{C}_{4}\right.$ or $\left.\mathrm{C}_{5}\right), 35.4\left(\mathrm{~s}, \mathrm{C}_{2}\right)$. IR (ATR): $\nu$ 2947, 2054, 1969, 1456, 1383, 1130, 1094, 766, 743. HRMS (ESI + ): calcd for $[\mathrm{M}+\mathrm{H}]^{+}=\mathrm{C}_{11} \mathrm{H}_{11} \mathrm{ClIrN}_{2} \mathrm{O}_{2}{ }^{+}, 431.0125$; found, 431.0129.

$5^{\mathrm{s}}$. Benzodithiolium tetrafluoroborate $(500 \mathrm{mg}, 2.08 \mathrm{mmol}, 1.0$ equiv) and silver(I) acetate (695.3 mg, $4.17 \mathrm{mmol}, 2.0$ equiv) were suspended in THF $(30 \mathrm{~mL})$ and heated to reflux for $20 \mathrm{~min}$. After it was cooled to room temperature, the green reaction mixture was filtered by cannula filtration. The remaining dark gray residue was washed with THF $(2 \times 5 \mathrm{~mL})$ and extracted into acetonitrile $(6 \times 5$ $\mathrm{mL})$. During the extraction, the receiving flask was cooled to $-78{ }^{\circ} \mathrm{C}$ in order to freeze the acetonitrile solution and avoid decomposition. Volatiles were removed under vacuum at room temperature to give $5^{\mathrm{S}}$ as a gray solid. Yield: $473 \mathrm{mg}$ (91\%). Crystals of poor but sufficient quality for X-ray crystallography were grown at $4{ }^{\circ} \mathrm{C}$ by vapor diffusion of hexanes into a concentrated solution of $5^{\mathrm{S}}$ in dichloromethane. Slightly longer reflux times (e.g., $40 \mathrm{~min}$ ) during the synthesis resulted in complete decomposition. The compound was moderately stable in chlorinated solvents but decomposed rapidly (mostly to dibenzotetrathiofulvalene and an unknown insoluble residue) in the presence of coordinating solvents such as acetonitrile or THF and was best stored in the solid state at $-20^{\circ} \mathrm{C}$ in the dark. ${ }^{40}$ $\mathrm{Mp}:>70{ }^{\circ} \mathrm{C}$ dec. ${ }^{1} \mathrm{H}$ NMR $\left(400 \mathrm{MHz}, \mathrm{CD}_{3} \mathrm{CN}\right): \delta 8.55\left(\mathrm{~m}, 4 \mathrm{H}, \mathrm{H}_{3}\right.$ or $\left.\mathrm{H}_{4}\right), 7.82\left(\mathrm{~m}, 4 \mathrm{H}, \mathrm{H}_{3}\right.$ or $\left.\mathrm{H}_{4}\right) .{ }^{13} \mathrm{C}\left\{{ }^{1} \mathrm{H}\right\} \mathrm{NMR}\left(100 \mathrm{MHz}, \mathrm{CD}_{3} \mathrm{CN}\right)$ : $\delta 150.6\left(\mathrm{~s}, \mathrm{C}_{2}\right), 129.3\left(\mathrm{~s}, \mathrm{C}_{3}\right.$ or $\left.\mathrm{C}_{4}\right), 125.2\left(\mathrm{~s}, \mathrm{C}_{3}\right.$ or $\left.\mathrm{C}_{4}\right), \mathrm{C}_{1}$ not detected. ${ }^{11} \mathrm{~B}\left\{{ }^{1} \mathrm{H}\right\}$ NMR $\left(128 \mathrm{MHz}, \mathrm{CD}_{3} \mathrm{CN}\right): \delta-1.2\left(\mathrm{~s}, \mathrm{BF}_{4}\right)$. ${ }^{19} \mathrm{~F}\left\{{ }^{1} \mathrm{H}\right\}$ NMR $\left(235 \mathrm{MHz}, \mathrm{CD}_{3} \mathrm{CN}\right): \delta-151.7$ (s). IR (ATR): $\nu$ 3090, 3055, 1439, 1427, 1088, 1030, 964, 950, 758. HRMS (ESI+): calcd for $\left[\mathrm{M}-\mathrm{BF}_{4}\right]^{+}=\mathrm{C}_{14} \mathrm{H}_{8} \mathrm{AgS}_{4}{ }^{+}, 410.8554$; found, 410.8548 .

$6^{\mathrm{S}}$. The iridium dimer complex $(67.3 \mathrm{mg}, 0.1 \mathrm{mmol}, 1.0$ equiv $)$ and $5^{\mathrm{S}}(100.0 \mathrm{mg}, 0.2 \mathrm{mmol}, 2.0$ equiv) were suspended in dichloromethane $(8 \mathrm{~mL})$ and stirred at ambient temperature for $30 \mathrm{~min}$. The brown reaction mixture was filtered over a pad of Celite which was subsequently rinsed with dichloromethane $(20 \mathrm{~mL})$. The clear brown solution was concentrated under vacuum to a volume of ca. $2 \mathrm{~mL}$. Addition of pentane $(20 \mathrm{~mL})$ led to the precipitation of a solid which was isolated by cannula filtration, washed with diethyl ether $(3 \times 3$ $\mathrm{mL}$ ), and dried under vacuum to give $\mathbf{6}^{\mathrm{S}}$ as a dark brown solid. Yield: $100 \mathrm{mg}$ (73\%). Crystals suitable for X-ray crystallography were grown at $4{ }^{\circ} \mathrm{C}$ by layering a concentrated solution of $6^{\mathrm{S}}$ in fluorobenzene/ dichloromethane $(1 / 1)$ with fluorobenzene. Mp: $>120{ }^{\circ} \mathrm{C}$ dec. ${ }^{1} \mathrm{H}$ NMR $\left(400 \mathrm{MHz}, \mathrm{CDCl}_{3}\right): \delta 8.21-8.16\left(\mathrm{~m}, 4 \mathrm{H}, \mathrm{H}_{3}\right.$ or $\left.\mathrm{H}_{4}\right), 7.61-$ $7.56\left(\mathrm{~m}, 4 \mathrm{H}, \mathrm{H}_{3}\right.$ or $\left.\mathrm{H}_{5}\right), 4.52\left(\mathrm{~m}, 4 \mathrm{H}, \mathrm{H}_{5}\right), 2.65-2.48\left(\mathrm{~m}, 8 \mathrm{H}, \mathrm{H}_{6}\right)$. ${ }^{13} \mathrm{C}\left\{{ }^{1} \mathrm{H}\right\}$ NMR $\left(100 \mathrm{MHz}, \mathrm{CDCl}_{3}\right): \delta 240.6\left(\mathrm{~s}, \mathrm{C}_{1}\right), 147.1\left(\mathrm{~s}, \mathrm{C}_{2}\right)$, $128.0\left(\mathrm{~s}, \mathrm{C}_{3}\right.$ or $\left.\mathrm{C}_{4}\right), 123.9\left(\mathrm{~s}, \mathrm{C}_{3}\right.$ or $\left.\mathrm{C}_{4}\right), 90.7\left(\mathrm{~s}, \mathrm{C}_{5}\right), 31.8\left(\mathrm{~s}, \mathrm{C}_{6}\right)$. ${ }^{11} \mathrm{~B}\left\{{ }^{1} \mathrm{H}\right\}$ NMR $\left(128 \mathrm{MHz}, \mathrm{CDCl}_{3}\right): \delta-0.7\left(\mathrm{~s}, \mathrm{BF}_{4}\right) .{ }^{19} \mathrm{~F}\left\{{ }^{1} \mathrm{H}\right\} \mathrm{NMR}$ $\left(235 \mathrm{MHz}, \mathrm{CDCl}_{3}\right): \delta-152.8$. IR (ATR): $\nu$ 3090, 3045, 2955, 2881, 2837, 1435, 1026, 926, 847, 752. HRMS (ESI+): calcd for [M $\left.\mathrm{BF}_{4}\right]^{+}=\mathrm{C}_{15} \mathrm{H}_{16} \mathrm{IrS}_{2}^{+}$, 453.0314; found, 453.0310.

$7^{5}$. Dichloromethane $(10 \mathrm{~mL})$ was slowly added to a copper bromide dimethyl sulfide complex ( $41.2 \mathrm{mg}, 0.2 \mathrm{mmol}, 1.0$ equiv) and $5^{\mathrm{S}}(100 \mathrm{mg}, 0.2 \mathrm{mmol}, 1.0$ equiv) and stirred at ambient temperature for $30 \mathrm{~min}$. The green reaction mixture was filtered over a pad of Celite. The clear dark green solution was evaporated to dryness. The brown residue was washed with diethyl ether $(3 \times 2 \mathrm{~mL})$ and dried under vacuum to give $7^{\mathrm{s}}$ as a brown solid. Yield: $67 \mathrm{mg}(74 \%) . \mathrm{Mp}$ : $>85-120{ }^{\circ} \mathrm{C}$ dec. ${ }^{1} \mathrm{H}$ NMR $\left(400 \mathrm{MHz}, \mathrm{CD}_{2} \mathrm{Cl}_{2}\right): \delta 8.49-8.47(\mathrm{~m}$, $4 \mathrm{H}, \mathrm{H}_{3}$ or $\left.\mathrm{H}_{4}\right)$, 7.84-7.82 (m, $4 \mathrm{H}, \mathrm{H}_{3}$ or $\left.\mathrm{H}_{4}\right) .{ }^{13} \mathrm{C}\left\{{ }^{1} \mathrm{H}\right\}$ NMR $(100$ $\left.\mathrm{MHz}, \mathrm{CD}_{2} \mathrm{Cl}_{2}\right) \delta 235.4\left(\mathrm{~s}, \mathrm{C}_{1}\right), 149.7\left(\mathrm{~s}, \mathrm{C}_{2}\right), 129.1\left(\mathrm{~s}, \mathrm{C}_{3}\right.$ or $\left.\mathrm{C}_{4}\right)$, 
124.5 (s, $\mathrm{C}_{3}$ or $\left.\mathrm{C}_{4}\right) .{ }^{11} \mathrm{~B}\left\{{ }^{1} \mathrm{H}\right\}$ NMR $\left(128 \mathrm{MHz}, \mathrm{CD}_{2} \mathrm{Cl}_{2}\right): \delta-0.83$ (s). ${ }^{19} \mathrm{~F}\left\{{ }^{1} \mathrm{H}\right\}$ NMR $\left(235 \mathrm{MHz}, \mathrm{CD}_{2} \mathrm{Cl}_{2}\right): \delta-150.5$ (s). IR (ATR): $\nu 3069$, $3055,1439,1429,1340,1285,1095,948,760$. HRMS (ESI+): calcd for $\left[\mathrm{M}-\mathrm{BF}_{4}\right]^{+}=\mathrm{C}_{14} \mathrm{H}_{8} \mathrm{CuS}_{4}{ }^{+}, 366.8799$; found, 366.8792 .

$8^{\mathrm{S}}$. A gold chloride dimethyl sulfide complex $(29.5 \mathrm{mg}, 0.1 \mathrm{mmol}$, 1.0 equiv) and $5^{\mathrm{s}}$ (50 mg, $0.1 \mathrm{mmol}, 1.0$ equiv) were suspended in dichloromethane and stirred at ambient temperature for $30 \mathrm{~min}$. The green reaction mixture was filtered via cannula. The clear dark green solution was concentrated under vacuum to a volume of ca. $1 \mathrm{~mL}$. Addition of pentane $(10 \mathrm{~mL})$ led to the precipitation of a solid which was isolated by cannula filtration, washed with diethyl ether $(3 \times 3$ $\mathrm{mL})$, and dried under vacuum to give $\mathbf{8}^{\mathrm{S}}$ as a gray-greenish solid. Yield: $52 \mathrm{mg}$ (88\%). Mp: $110-140{ }^{\circ} \mathrm{C}$ dec. ${ }^{1} \mathrm{H}$ NMR (400 MHz, $\left.\mathrm{CD}_{2} \mathrm{Cl}_{2}\right): \delta 8.53\left(\mathrm{~m}, 4 \mathrm{H}, \mathrm{H}_{3}\right.$ or $\left.\mathrm{H}_{4}\right), 7.94\left(\mathrm{~m}, 4 \mathrm{H}, \mathrm{H}_{3}\right.$ or $\left.\mathrm{H}_{4}\right) .{ }^{13} \mathrm{C}\left\{{ }^{1} \mathrm{H}\right\}$ NMR $\left(100 \mathrm{MHz}, \mathrm{CD}_{2} \mathrm{Cl}_{2}\right): \delta 232.0\left(\mathrm{~s}, \mathrm{C}_{1}\right), 147.6\left(\mathrm{~s}, \mathrm{C}_{2}\right), 129.9(\mathrm{~s}$, $\mathrm{C}_{3}$ or $\left.\mathrm{C}_{4}\right), 125.2\left(\mathrm{~s}, \mathrm{C}_{3}\right.$ or $\left.\mathrm{C}_{4}\right) .{ }^{11} \mathrm{~B}\left\{{ }^{1} \mathrm{H}\right\} \mathrm{NMR}\left(128 \mathrm{MHz}, \mathrm{CD}_{2} \mathrm{Cl}_{2}\right): \delta$ $-1.1\left(\mathrm{~s}, \mathrm{BF}_{4}\right) .{ }^{19} \mathrm{~F}\left\{{ }^{1} \mathrm{H}\right\}$ NMR $\left(235 \mathrm{MHz}, \mathrm{CD}_{2} \mathrm{Cl}_{2}\right): \delta-151.1$ (sbr, $\mathrm{BF}_{4}$ ). IR (ATR): $\nu$ 3099, 3056, 1549, 1433, 1326, 1312, 1286, 1259, 1095, 1034, 758. HRMS (ESI+): calcd for $\left[\mathrm{M}-\mathrm{BF}_{4}\right]^{+}=\mathrm{C}_{14} \mathrm{H}_{8} \mathrm{AuS}_{4}{ }_{4}$, 500.9169; found, 500.9188.

Computational Details. Calculations on the free carbenes were performed at the DFT B3LYP/TZVP level of theory using Gaussian09, Revision A.02. ${ }^{41,42}$ Those on the carbene metal complexes were performed using the parallelized Amsterdam density functional (ADF) package (version 2014.04). ${ }^{43}$ The Kohn-Sham MOs were expanded in a large, uncontracted basis set of Slater-type orbitals (STOs), of a triple- $\zeta$ basis set with two polarization function quality, corresponding to basis set TZ2P in the ADF package. All calculations were performed at the nonlocal exchange self-consistent field (NL-SCF) level, using the local density approximation (LDA) in the Vosko-Wilk-Nusair parametrization ${ }^{44}$ with nonlocal corrections for exchange (Becke88) ${ }^{45}$ and correlation (Perdew86) ${ }^{46}$ and with Grimme-type dispersion correction (D3-BJ). ${ }^{47}$ All geometries were optimized using the analytical gradient method implemented by Versluis and Ziegler, ${ }^{48}$ including relativistic effects by the zeroth-order regular approximation (ZORA). ${ }^{49}$

The bonding interactions of the transition-metal to ligand bonds were analyzed with the ADF implemented energy decomposition ${ }^{50}$ into an exchange (or Pauli) repulsion $\left(\Delta E_{\text {Pauli }}\right)$ between the electrons on the two fragments plus an electrostatic interaction energy part $\left(\Delta E_{\text {elstat }}\right)$ and an orbital interaction energy (charge transfer, polarization) part $\left(\Delta E_{\text {orb }}\right)$. The energy necessary to convert fragments from their ground-state equilibrium geometries to the geometry and electronic state they acquire in the complex is represented by a preparation energy term $\left(\Delta E_{\text {prep }}\right)$. The overall bond energy $\left(\Delta E_{\text {tot }}\right)$ is formulated as

$$
\Delta E_{\text {tot }}=\Delta E_{\text {Pauli }}+\Delta E_{\text {elstat }}+\Delta E_{\text {orb }}+\Delta E_{\text {prep }}
$$

Note that $\Delta E_{\text {tot }}$ is defined as the negative of the bond dissociation energy (BDE), i.e. $\Delta E_{\text {tot }}=E$ (molecule $)-\sum E($ fragments $)$, thereby resulting in negative values for stable bonds. The orbital interaction term $\Delta E_{\text {orb }}$ accounts for interactions between occupied orbitals on one fragment with unoccupied orbitals on the other fragment, including HOMO-LUMO interactions and polarization (empty/ occupied orbital mixing on the same fragment). The charge transfer part is the result of both $\sigma$ donation from the ligand to the metal and $\pi$ back-donation from the metal into the unoccupied orbitals of the ligand. Instead of separating the charge transfer and polarization parts, we used the extended transition state (ETS) method developed by Ziegler and Rauk to decompose $\Delta E_{\text {orb }}$ into contributions from each irreducible representation of the interacting system. ${ }^{50}$

X-ray Structure Determination. The crystal structures were determined on a Bruker D8 Venture diffractometer with Photon 100 detector at $123(2) \mathrm{K}$ using Mo K $\alpha$ radiation $\left(2^{\mathrm{O}}, 2^{\mathrm{N}}, 3^{\mathrm{N}}, 3^{\mathrm{O}}, 3^{\mathrm{S}}, 6^{\mathrm{S}}\right)$ $(0.71073 \AA)$. Direct methods $\left(2^{\mathrm{O}}, 3^{\mathrm{O}}, \mathbf{6}^{\mathrm{S}}\right)$ or Patterson methods $\left(2^{\mathrm{N}}\right.$, $3^{\mathrm{N}}, 3^{\mathrm{S}}$ ) were used for structure solution (SHELXS-97). ${ }^{51}$ Refinement was carried out using SHELXL-2014 (full-matrix least-squares on $\left.F^{2}\right)^{52}$ and hydrogen atoms were localized by difference Fourier synthesis and refined using a riding model. Semiempirical absorption corrections were applied for the compounds. For $2^{\mathrm{O}}, 2^{\mathrm{N}}, 3^{\mathrm{N}}, 3^{\mathrm{O}}$, and $3^{\mathrm{S}}$ extinction corrections were applied. ${ }^{53} 3^{\mathrm{N}}$ was refined as a twocomponent inversion twin $(\mathrm{BASF}=0.277(7))$. In $\mathbf{6}^{\mathrm{s}}$ one solvent molecule is disordered about a 2 -fold axis (see cif file for details). CCDC $1451141\left(\mathbf{2}^{\mathbf{O}}\right), \operatorname{CCDC} 1451142\left(\mathbf{2}^{\mathbf{N}}\right), \operatorname{CCDC} 1451143\left(\mathbf{3}^{\mathbf{N}}\right)$, CCDC $1451144\left(3^{\mathrm{o}}\right), \operatorname{CCDC} 1451145\left(3^{\mathrm{s}}\right), \operatorname{CCDC} 1451203\left(\mathbf{5}^{\mathrm{s}}\right)$, and $1451146\left(6^{\mathrm{S}}\right)$ contain the supplementary crystallographic data for this paper. Additional crystallographic information is available in the Supporting Information.

\section{ASSOCIATED CONTENT}

\section{SI Supporting Information}

The Supporting Information is available free of charge at https://pubs.acs.org/doi/10.1021/acs.organomet.0c00066.

NMR spectra, additional computational details and crystallographic data, geometries of computed structures (PDF)

$$
\text { Computed Cartesian coordinates (XYZ) }
$$

\section{Accession Codes}

CCDC 1451141-1451146 and 1451203 contain the supplementary crystallographic data for this paper. These data can be obtained free of charge via www.ccdc.cam.ac.uk/data_request/ cif, or by emailing data_request@ccdc.cam.ac.uk, or by contacting The Cambridge Crystallographic Data Centre, 12 Union Road, Cambridge CB2 1EZ, UK; fax: +44 1223336033.

\section{AUTHOR INFORMATION}

\section{Corresponding Author}

Koop Lammertsma - Department of Chemistry and Pharmaceutical Sciences, Faculty of Science, Vrije Universiteit Amsterdam, 1081 HV Amsterdam, The Netherlands; Department of Chemistry, University of Johannesburg, Johannesburg 2006, South Africa; 이이. orcid.org/0000-00019162-5783; Email: K.Lammertsma@vu.nl

\section{Authors}

Maximilian Joost - Department of Chemistry and Pharmaceutical Sciences, Faculty of Science, Vrije Universiteit Amsterdam, 1081 HV Amsterdam, The Netherlands

Martin Nieger - Laboratory of Inorganic Chemistry, Department of Chemistry, University of Helsinki, Helsinki, Finland

Martin Lutz - Crystal and Structural Chemistry, Bijvoet Center for Biomolecular Research, Utrecht University, $3584 \mathrm{CH}$ Utrecht, The Netherlands

Andreas W. Ehlers - Department of Chemistry and Pharmaceutical Sciences, Faculty of Science, Vrije Universiteit Amsterdam, 1081 HV Amsterdam, The Netherlands; Van ' $t$ Hoff Institute for Molecular Sciences, University of Amsterdam, 1090 GD Amsterdam, The Netherlands; Department of Chemistry, University of Johannesburg, Johannesburg 2006, South Africa

J. Chris Slootweg - Department of Chemistry and Pharmaceutical Sciences, Faculty of Science, Vrije Universiteit Amsterdam, 1081 HV Amsterdam, The Netherlands; Van ' $t$ Hoff Institute for Molecular Sciences, University of Amsterdam, 1090 GD Amsterdam, The Netherlands; 이이.org/00000001-7818-7766

Complete contact information is available at: https://pubs.acs.org/10.1021/acs.organomet.0c00066

\section{Notes}

The authors declare no competing financial interest. 


\section{ACKNOWLEDGMENTS}

This work was supported by The Netherlands Organisation for Scientific Research, Chemical Sciences (NWO-CW). We acknowledge SARA Computing and Networking Services for computer time.

\section{REFERENCES}

(1) (a) Arduengo, A. J.; Harlow, R. L.; Kline, M. A Stable Crystalline Carbene. J. Am. Chem. Soc. 1991, 113, 361-363. (b) Hahn, F. E.; Jahnke, M. C. Heterocyclic Carbenes: Synthesis and Coordination Chemistry. Angew. Chem., Int. Ed. 2008, 47, 3122-3172; Angew. Chem. 2008, 120, 3166-3216. (c) N-Heterocyclic Carbenes; DíezGonzález, S., Ed.; Royal Society of Chemistry: Cambridge, U.K., 2010. (d) Hopkinson, M. N.; Richter, C.; Schedler, M.; Glorius, F. An Overview of N-Heterocyclic Carbenes. Nature 2014, 510, 485-496.

(2) (a) Melaimi, M.; Soleilhavoup, M.; Bertrand, G. Stable Cyclic Carbenes and Related Species beyond Diaminocarbenes. Angew. Chem., Int. Ed. 2010, 49, 8810-8849; Angew. Chem. 2010, 122, 8992-9032. (b) Wang, Y.; Robinson, G. H. N-Heterocyclic Carbene-Main-Group Chemistry: A Rapidly Evolving Field. Inorg. Chem. 2014, 53, 11815-11832.

(3) (a) Trnka, T. M.; Grubbs, R. H. CHR Olefin Metathesis Catalysts: An Organometallic Success Story. Acc. Chem. Res. 2001, 34, 18-29. (b) Glorius, F. N-Heterocyclic Carbenes in Transition Metal Catalysis; Springer Science \& Business Media: 2007. (c) Enders, D.; Niemeier, O.; Henseler, A. Organocatalysis by N-Heterocyclic Carbenes. Chem. Rev. 2007, 107, 5606-5655. (d) Díez-González, S.; Marion, N.; Nolan, S. P. N-Heterocyclic Carbenes in Late Transition Metal Catalysis. Chem. Rev. 2009, 109, 3612-3676. (e) Cazin, C. S. J. N-Heterocyclic Carbenes in Transition Metal Catalysis and Organocatalysis; Springer Science \& Business Media: 2010.

(4) Mercs, L.; Albrecht, M. Beyond Catalysis: N-Heterocyclic Carbene Complexes as Components for Medicinal, Luminescent, and Functional Materials Applications. Chem. Soc. Rev. 2010, 39, 19031912.

(5) (a) Mercs, L.; Labat, G.; Neels, A.; Ehlers, A. W.; Albrecht, M. Piano-Stool Iron(II) Complexes as Probes for the Bonding of NHeterocyclic Carbenes: Indications for $\pi$-Acceptor Ability. Organometallics 2006, 25, 5648-5656. (b) Jacobsen, H.; Correa, A.; Poater, A.; Costabile, C.; Cavallo, L. Understanding the M-(NHC) $(\mathrm{NHC}=$ N-Heterocyclic Carbene) Bond. Coord. Chem. Rev. 2009, 253, 687703. (c) Nelson, D. J.; Nolan, S. P. Quantifying and Understanding the Electronic Properties of N-Heterocyclic Carbenes. Chem. Soc. Rev. 2013, 42, 6723-6753. (d) Alcarazo, M.; Stork, T.; Anoop, A.; Thiel, W.; Fürstner, A. Steering the Surprisingly Modular $\pi$-Acceptor Properties of N-Heterocyclic Carbenes: Implications for Gold Catalysis. Angew. Chem., Int. Ed. 2010, 49, 2542-2546; Angew. Chem. 2010, 122, 2596-2600.

(6) (a) Würtz, S.; Glorius, F. Surveying Sterically Demanding NHeterocyclic Carbene Ligands with Restricted Flexibility for Palladium-catalyzed Cross-Coupling Reactions. Acc. Chem. Res. 2008, 41, 1523-1533. (b) Droge, T.; Glorius, F. The Measure of All Rings-N-Heterocyclic Carbenes. Angew. Chem., Int. Ed. 2010, 49, 6940-6952; Das Maß aller Ringe - N-heterocyclische Carbene. Angew. Chem. 2010, 122, 7094-7107. (c) Benhamou, L.; Chardon, E.; Lavigne, G.; Bellemin-Laponnaz, S.; César, V. Synthetic Routes to N-Heterocyclic Carbene Precursors. Chem. Rev. 2011, 111, 27052733.

(7) Soleilhavoup, M.; Bertrand, G. Cyclic (Alkyl)(Amino)Carbenes (CAACs): Stable Carbenes on the Rise. Acc. Chem. Res. 2015, 48, 256-266.

(8) Rao, B.; Tang, H.; Zeng, X.; Liu, L.; Melaimi, M.; Bertrand, G. Cyclic (Amino)(aryl)carbenes (CAArCs) as Strong $\sigma$-Donating and $\pi$-Accepting Ligands for Transition Metals. Angew. Chem., Int. Ed. 2015, 54, 14915-14919; Angew. Chem. 2015, 127, 15128-15132.

(9) (a) Plaia, U.; Stolzenberg, H.; Fehlhammer, W. P. Homoleptic Carbene Complexes. 3. Hexakis(oxazolidin-2-ylidene)cobalt(III) and -rhodium(III). J. Am. Chem. Soc. 1985, 107, 2171-2172. (b) Tamm,
M.; Ekkehardt Hahn, F. Reactions of $\beta$-Functional Phenyl Isocyanides. Coord. Chem. Rev. 1999, 182, 175-209. (c) Lindner, R.; Wagner, C.; Steinborn, D. Synthesis of Trimethylplatinum(IV) Complexes with N, N- and N, O-Heterocyclic Carbene Ligands and Their Reductive C-C Elimination Reactions. J. Am. Chem. Soc. 2009, 131, 8861-8874. (d) Bellemin-Laponnaz, S. Synthesis of N, OHeterocyclic Carbene and Coordination to Rhodium(I) and Copper(I). Polyhedron 2010, 29, 30-33.

(10) (a) Cardin, D. J.; Cetinkaya, B.; Cetinkaya, E.; Lappert, M. F. Carbene Complexes. Part I. Electron-rich Olefins as a Source of Carbene Complexes of Platinum(II) and Palladium(II); and Some Experiments with $\left(\mathrm{CF}_{3}\right)_{2} \mathrm{CN}_{2}$. J. Chem. Soc., Dalton Trans. 1973, 514-522. (b) Raubenheimer, H. G.; Kruger, G. J.; Van A. Lombard, A.; Linford, L.; Viljoen, J. C. Sulfur-Containing Metal Complexes. 12. Reactions of $\alpha$-Thio Carbanions with Carbene Complexes of the Type $\left[\mathrm{M}(\mathrm{CO})_{5}\{\mathrm{O}(\mathrm{alkyl}) \mathrm{Ar}\}\right]$ and with the Carbyne $\left[\left(\eta^{5}-\mathrm{MeC}_{5} \mathrm{H}_{4}\right)-\right.$ $\left.\mathrm{Mn}(\mathrm{CO})_{2}(\mathrm{CPh})\right]\left[\mathrm{BCl}_{4}\right]$. Organometallics 1985, 4, 275-284. (c) Johnson, L.; Angelici, R. J. Synthesis of Aminooxycarbene Complexes of Iron with N-Alkyl, -Allyl, -Carbamoyl Groups. Inorg. Chem. 1987, 26, 973-976. (d) Bertani, R.; Mozzon, M.; Michelin, R. A. Reactions of Aziridine, Thiirane, and Oxirane with Isocyanide Ligands in Complexes of Palladium(II) and Platinum(II): Syntheses of Neutral Five-Membered Cyclic Diamino-, Aminothio-, and Aminooxycarbene Compounds. Inorg. Chem. 1988, 27, 2809-2815. (e) Arduengo, A. J.; Goerlich, J. R.; Marshall, W. J. A Stable Thiazol-2-ylidene and Its Dimer. Liebigs Ann. 1997, 1997, 365-374. (f) Caló, V.; Sole, R. D.; Nacci, A.; Schingaro, E.; Scordari, F. Synthesis and Crystal Structure of Bis(2,3-dihydro-3-methylbenzothiazole-2-ylidene)palladium(II) Diiodide: The First Palladium Complex with Benzothiazole Carbene Ligands Suitable for Homogeneous Catalysis. Eur. J. Org. Chem. 2000, 2000, 869-871. (g) Caló, V.; Nacci, A.; Monopoli, A.; Spinelli, M. Arylation of Allylic Alcohols in Ionic Liquids Catalysed by a PdBenzothiazole Carbene Complex. Eur. J. Org. Chem. 2003, 2003, 1382-1385. (h) Enders, D.; Balensiefer, T. Nucleophilic Carbenes in Asymmetric Organocatalysis. Acc. Chem. Res. 2004, 37, 534-541. (i) Huynh, H. V.; Meier, N.; Pape, T.; Hahn, F. E. Benzothiazolin-2ylidene Complexes of Iridium(I). Organometallics 2006, 25, 30123018. (j) Chien, S. W.; Yen, S. K.; Hor, T. S. A. N, S-Heterocyclic Carbene Complexes. Aust. J. Chem. 2010, 63, 727-741.

(11) (a) Hahn, F. E. Heterocyclic Carbenes. Angew. Chem., Int. Ed. 2006, 45, 1348-1352; Angew. Chem. 2006, 118, 1374-1378. (b) de Fremont, F.; Marion, N.; Nolan, S. P. Carbenes: synthesis, properties, and organometallic chemistry. Coord. Chem. Rev. 2009, 253, 862-892. (c) Kuwata, S.; Hahn, F. E. Complexes bearing protic N-heterocyclic carbene ligands. Chem. Rev. 2018, 118, 9642-9677.

(12) Taxak, N.; Patel, B.; Bharatam, P. V. Carbene Generation by Cytochromes and Electronic Structure of Heme-Iron-PorphyrinCarbene Complex: A Quantum Chemical Study. Inorg. Chem. 2013, 52, 5097-5109.

(13) (a) Green, M.; Moss, J. R.; Nowell, I. W.; Stone, F. G. A. Synthesis of Manganese(I) Carbene Complexes. J. Chem. Soc., Chem. Commun. 1972, 1339-1340. (b) Bowen, D. H.; Green, M.; Grove, D. M.; Moss, J. R.; Stone, F. G. A. Chemistry of the Metal Carbonyls. Part LXIX. Synthesis and Reactions of Complexes of Manganese Containing the Substituted and Unsubstituted 2,5-Dioxacyclopentylidene Ligand. J. Chem. Soc., Dalton Trans. 1974, 1189-1194. (c) Daub, J.; Kappler, J. Thionocarbonat-Komplexe mit Übergangsmetallen der Gruppe VIB. Synthese von Eisentetracarbonyl-CarbenComplexen. J. Organomet. Chem. 1974, 80, C5-C8. (d) Pfiz, R.; Daub, J. Synthese und Struktur eines Benzodioxol-2-yliden-EisenKomplexes. J. Organomet. Chem. 1978, 152, C32-C34. (e) Le Bozec, H.; Gorgues, A.; Dixneuf, P. H. Novel Route to Iron-Carbene Derivatives via Addition of Alkynes to Carbon Disulfide-Iron Complexes. Rearrangement of 91,3-Dithiol-2-ylidene)iron Complexes into Heterometallacycles. Inorg. Chem. 1981, 20, 2486-2489. (f) Daub, J.; Endress, G.; Erhardt, U.; Jogun, K. H.; Kappler, J.; Laumer, A.; Pfiz, R.; Stezowski, J. J. Desulfurierungsreaktionen mit Eisencarbonyl-Verbindungen: Carbonyl(dioxolanyliden)-eisen-Komplexe aus Thionocarbonaten. Chem. Ber. 1982, 115, 1787-1809. 
(g) Motschi, H.; Angelici, R. J. Synthesis of Cyclic Aminooxo- and Dioxocarbenes from Carbonyl Ligands in Complexes of Iron and Manganese. Organometallics 1982, 1, 343-349. (h) Singh, M. M.; Angelici, R. J. Dioxy Carbene Complexes from Reactions of $\mathrm{Fe}(\mathrm{CO})_{5}$, $\mathrm{Mn}(\mathrm{CO})_{10}, \operatorname{Re}_{2}(\mathrm{CO})_{10}$ and $\mathrm{Ru}(\mathrm{CO})_{12}$ with Oxirane. Inorg. Chim. Acta 1985, 100, 57-63. (i) Michelin, R. A.; Facchin, G.; Ros, R. Preparation of New Hydridoplatinum(II) Carbene Derivatives from Hydridotrifluoromethyl Complexes. J. Organomet. Chem. 1985, 279, C25-C28. (i) Miessler, G. L.; Kim, S.; Jacobson, R. A.; Angelici, R. J. Synthesis, Reactions, and Structures of Dioxycarbene Complexes of Rhenium. Inorg. Chem. 1987, 26, 1690-1695. (j) Wang, S.-J.; Miller, L. L.; Jacobson, R. A.; Angelici, R. J. Synthesis, Structure, and Catalytic Reactions of Dioxycarbene Complexes of Iron and Osmium. Inorg. Chim. Acta 1988, 145, 129-137. (k) Andrews, M. A.; Myles, W. L. Ketone-like Derivatization Reactions of Metal Carbonyls. Attempts to Measure the Equilibrium Constant for Ketalization of a Carbonyl Ligand in $\left[\mathrm{R}(\mathrm{CO})_{6}\right]^{+}$by Ethylene Glycol. Inorg. Chem. 1988, 27, 1118-1120. (1) Michelin, R. A.; Ros, R.; Guadalupi, G.; Bombieri, G.; Benetollo, F.; Chapuis, G. Electrophilic Cleavage of Carbon-Fluorine Bonds in Hydrido Trifluoromethyl Complexes of Platinum(II) by Proton Acids. Synthesis of Hydrido Carbene and Hydrido Carbonyl Derivatives and X-ray Structures of trans- $\mathrm{PtH}\left(\mathrm{CF}_{3}\right)\left(\mathrm{PPh}_{3}\right)^{2}(180 \mathrm{~K})$ and trans- $\left[\mathrm{PtH}[\mathrm{cyclic}]\left(\mathrm{COCH}_{2} \mathrm{CH}_{2} \mathrm{O}\right)\left(\mathrm{PPh}_{3}\right)_{2}\right] \mathrm{BF}_{4}(298 \mathrm{~K})$. Inorg. Chem. 1989, 28, 840-846. (m) Glavee, G. N.; Su, Y.; Jacobson, R. A.; Angelici, R. Reactions of $\mathrm{CpFe}(\mathrm{CO})_{2}\left(=[\text { cyclic }]\left(\mathrm{COCH}_{2} \mathrm{CH}_{2} \mathrm{O}\right)\right)^{+}$, $\mathrm{CpFe}(\mathrm{CO})_{2}\left[=\mathrm{C}(\mathrm{SMe})_{2}\right]^{+}$and Related Carbene Complexes with Reducing Agents and Nucleophiles. The Structure of $\{\mathrm{CpFe}-$ $\left.(\mathrm{CO})_{2}\left[=\mathrm{C}(\mathrm{SMe})_{2}\right]\right\} \mathrm{PF}_{6}$. Inorg. Chim. Acta 1989, 157, 73-84. (n) Miessler, G. L.; Kim, S.; Jacobson, R. A.; Angelici, R. J. Synthesis, Reactions, and Structures of Dioxycarbene Complexes of Rhenium. Inorg. Chem. 1987, 26, 1690-1695.

(14) (a) Le Bozec, H.; Gorgues, A.; Dixneuf, P. H. Novel Route to Iron-Carbene Complexes via $\eta^{2}-\mathrm{CS}_{2}$ Derivatives. 1,3-Dithiolium Species as Precursors for Dithiolene-Iron Complexes and Tetrathiafulvalenes. J. Am. Chem. Soc. 1978, 100, 3946-3947. (b) Le Marouille, J. Y.; Lelay, C.; Benoit, A.; Grandjean, D.; Touchard, D.; Le Bozec, H.; Dixneuf, P. Sulfur-Containing Carbene-Metal Compounds: General Route from Carbon Disulfide Manganese Complexes; X-ray Structure of 1,3-Dithiol-2-ylidenemanganese(I) Derivative. J. Organomet. Chem. 1980, 191, 133-142. (c) Le Bozec, H.; Gorgues, A.; Dixneuf, P. H. Novel Route to Iron-Carbene Derivatives via Addition of Alkynes to Carbon Disulfide-Iron Complexes. Rearrangement of 91,3-Dthiol-2-ylidene)iron Complexes into Heterometallacycles. Inorg. Chem. 1981, 20, 2486-2489. (d) Singh, M. M.; Angelici, R. J. Expansion of Three-Membered Heterocycles to Five-Membered Cyclic Carbenes-Novel Reactions of Aziridine, Oxirane, and Thiirane with CO and CS Ligands in Iron, Ruthenium, and Manganese Complexes. Angew. Chem., Int. Ed. Engl. 1983, 22, 163164; Angew. Chem. 1983, 95, 160. (e) Singh, M. M.; Angelici, R. J. Reactions of Aziridine, Oxirane and Thiirane with Carbonyl and Thiocarbonyl Ligands in Complexes of Iron, Manganese, and Ruthenium: Syntheses of Cyclic Carbene Compounds. Inorg. Chem. 1984, 23, 2691-2698. (f) Singh, M. M.; Angelici, R. J. Reactions of Aziridine and Oxirane with Manganese and Rhenium Carbonyl Complexes. Syntheses of Neutral 5-Membered Cyclic Aminooxy and Dioxycarbene Compounds. Inorg. Chem. 1984, 23, 2699-2705.

(15) (a) Liske, A.; Verlinden, K.; Buhl, H.; Schaper, K.; Ganter, C. Determining the $\pi$-Acceptor Properties of $\mathrm{N}$-Heterocyclic Carbenes by Measuring the ${ }^{77} \mathrm{Se}$ NMR Chemical Shifts of Their Selenium Adducts. Organometallics 2013, 32, 5269-5272. (b) Nelson, D. J.; Collado, A.; Manzini, S.; Meiries, S.; Slawin, A. M. Z.; Cordes, D. B.; Nolan, S. P. Methoxy-Functionalized N-Heterocyclic Carbenes. Organometallics 2014, 33, 2048-2058. (c) Nelson, D. J.; Nahra, F.; Patrick, S. R.; Cordes, D. B.; Slawin, A. M. Z.; Nolan, S. P. Exploring the Coordination of Cyclic Selenoureas to Gold(I). Organometallics 2014, 33, 3640-3645. (d) Vummaleti, S. V. C.; Nelson, D. J.; Poater, A.; Gómez-Suárez, A.; Cordes, D. B.; Slawin, A. M. Z.; Nolan, S. P.; Cavallo, L. What can NMR Spectroscopy of Selenoureas and
Phosphinidenes Teach Us About the $\pi$-Accepting Abilities of $\mathrm{N}$ Heterocyclic Carbenes? Chem. Sci. 2015, 6, 1895-1904.

(16) For syntheses via olefin dissociation, see: (a) Cardin, D. J.; Cetinkaya, B.; Lappert, M. F. Transition metal-carbene complexes. Chem. Rev. 1972, 72, 545-574. (b) Cardin, D. J.; Cetinkaya, B.; Lappert, M. F.; Manojlović-Muir, L.; Muir, K. W. An electron-rich olefin as a source of coordinated carbene; synthesis of trans$\mathrm{PtCl}_{2}\left[\mathrm{C}\left(\mathrm{NPhCH}_{2}\right)_{2}\right] \mathrm{PEt}_{3}$. J. Chem. Soc. D 1971, 0, 400-401 For deprotonation and transmetallation routes see ref $1 \mathrm{c}$. and references therein.

(17) Tanaka, K.; Yoshida, K.; Ishida, T.; Kobayashi, A.; Nogami, T. First TOF Donors: Synthesis and Characterization of Dibenzo- and Dinaphthotetraoxafulvalenes. Adv. Mater. 2000, 12, 661-664.

(18) Due to decomposition of dibenzodithiolium tetrafluoroborate in the presence of $\left[\mathrm{IrCl}_{2}(\mathrm{cod})\right]$, accessing the desired SHC complex via deprotonation also failed.

(19) Gülcemal, S.; Gökçe, A. G.; Çetinkaya, B. Iridium(I) NHeterocyclic Carbene Complexes of Benzimidazol-2-ylidene: Effect of Electron Donating Groups on the Catalytic Transfer Hydrogenation Reaction. Dalton Trans. 2013, 42, 7305-7311.

(20) Ehlers, A. W.; Ruiz-Morales, Y.; Baerends, E. J.; Ziegler, T. Dissociation Energies, Vibrational Frequencies, and ${ }^{13} \mathrm{C}$ NMR Chemical Shifts of the 18-Electron Species $\left[\mathrm{M}(\mathrm{CO})_{6}\right]^{\mathrm{n}}(\mathrm{M}=\mathrm{Hf}-\mathrm{Ir}$, $\mathrm{Mo}, \mathrm{Tc}, \mathrm{Ru}, \mathrm{Cr}, \mathrm{Mn}, \mathrm{Fe})$. A Density Functional Study. Inorg. Chem. 1997, 36, 5031-5036.

(21) Scherowsky, G.; Weiland, J. Bildung und Reaktionen von 2Carbena-1,3-benzodithiolen; Umsetzungen von 1,3-Benzodithioliumsalzen. Justus Liebigs Ann. Chem. 1974, 1974, 403-411.

(22) Tapu, D.; Dixon, D. A.; Roe, C. ${ }^{13} \mathrm{C}$ NMR Spectroscopy of "Arduengo-type" Carbenes and Their Derivatives. Chem. Rev. 2009, 109, 3385-3407.

(23) Crystallographic data for $3^{\mathrm{N}}$ in a different space group were reported by: Meredith, J. M.; Robinson, R.; Goldberg, K. I.; Kaminsky, W.; Heinekey, D. M. C-H Bond Activation by Cationic Iridium(III) NHC Complexes: A Combined Experimental and Computational Study. Organometallics 2012, 31, 1879-1887.

(24) (a) Niehues, M.; Erker, G.; Kehr, G.; Schwab, P.; Fröhlich, R.; Blacque, O.; Berke, H. Synthesis and Structural Features of Arduengo Carbene Complexes of Group 4 Metallocene Cations. Organometallics 2002, 21, 2905-2911. (b) Aktas, H.; Slootweg, J. C.; Schakel, M.; Ehlers, A. W.; Lutz, M.; Spek, A. L.; Lammertsma, K. N-Heterocyclic Carbene-Functionalized Ruthenium Phosphinidenes: What a Difference a Twist Makes. J. Am. Chem. Soc. 2009, 131, 6666-6667.

(25) See also: Schilling, B. E. R.; Hoffmann, R.; Lichtenberger, D. L. $\mathrm{CpM}(\mathrm{CO})_{2}$ (ligand) $(\mathrm{Cp}=$ Cyclopentadienyl, $\mathrm{M}=$ Metal $)$ Complexes. J. Am. Chem. Soc. 1979, 101, 585-591.

(26) (a) Tolman, C. A. Steric Effects of Phosphorus Ligands in Organometallic Chemistry and Homogeneous Catalysis. Chem. Rev. 1977, 77, 313-348. (b) Kelly III, R. A.; Clavier, H.; Giudice, S.; Scott, N. M.; Stevens, E. D.; Bordner, J.; Samardjiev, I.; Hoff, C. D.; Cavallo, L.; Nolan, S. P. Determination of N-Heterocyclic Carbene (NHC) Steric and Electronic Parameters using the [(NHC)Ir$(\mathrm{CO})_{2} \mathrm{Cl}$ ] System. Organometallics 2008, 27, 202-210. (c) Wolf, S.; Plenio, H. Synthesis of ( $\mathrm{NHC}) \mathrm{Rh}(\operatorname{cod}) \mathrm{Cl}$ and $(\mathrm{NHC}) \mathrm{RhCl}(\mathrm{CO}) 2$ Complexes - Translation of the Rh-into the Ir-scale for the Electronic Properties of NHC Ligands. J. Organomet. Chem. 2009, 694, 14871492.

(27) Beck, G.; Lappert, M. F.; Hitchcock, P. B. Synthesis of the Sterically Hindered Complexes $\left[\mathrm{M}(\mathrm{CO})_{5}\left(\mathrm{CNBR}_{2}\right)\right][\mathrm{R}=\mathrm{CH}$ $(\mathrm{SiMe} 3) 2 ; \mathrm{M}=\mathrm{Cr}, \mathrm{Mo}$, or $\mathrm{W}]$. Crystal Structure of $[\mathrm{Cr}-$ $\left.(\mathrm{CO})_{5}\left(\mathrm{CNBR}_{2}\right)\right]$. J. Organomet. Chem. 1994, 468, 143-148.

(28) (a) Schönherr, H.-J.; Wanzlick, H.-W. Chemie Nucleophiler Carbene, XX HX-Abspaltung aus 1.3-Diphenylimidazoliumsalzen. Quecksilbersalz Carben Komplexe. Chem. Ber. 1970, 103, 10371046. (b) Guerret, O.; Solé, S.; Gornitzka, H.; Teichert, M.; Trinquier, G.; Bertrand, G. 1,2,4-Triazole-3,5-diylidene: A Building Block for Organometallic Polymer Synthesis. J. Am. Chem. Soc. 1997, 119, 6668-6669. (c) Guerret, O.; Solé, S.; Gornitzka, H.; Trinquier, G.; Bertrand, G. 1,2,4-Triazolium-5-ylidene and 1,2,4-Triazol-3,5- 
diylidene as New Ligands for Transition Metals. J. Organomet. Chem. 2000, 600, 112-117.

(29) A CCDC database search revealed that $\mathrm{C}-\mathrm{Ag}$ bond distances of structurally characterized linear bis( $\mathrm{NHC}) \mathrm{Ag}$ complexes span from about 2.017 to $2.161 \AA$.

(30) (a) Wang, H. M. J.; Lin, I. J. B. Facile Synthesis of Silver(I)Carbene Complexes. Useful Carbene Transfer Agents. Organometallics 1998, 17, 972-975. (b) Garrison, J. C.; Youngs, W. J. Ag(I) NHeterocyclic Carbene Complexes: Synthesis, Structure, and Application. Chem. Rev. 2005, 105, 3978-4008.

(31) (a) Boehme, C.; Frenking, G. N-Heterocyclic Carbene, Silylene, and Germylene Complexes of $\mathrm{MCl}(\mathrm{M}=\mathrm{Cu}, \mathrm{Ag}, \mathrm{Au})$. A Theoretical Study. Organometallics 1998, 17, 5801-5809. (b) Lin, J. C. Y.; Huang, R. T. W.; Lee, C. S.; Bhattacharyya, A.; Hwang, W. S.; Lin, I. J. B. Coinage Metal-N-Heterocyclic Carbene Complexes. Chem. Rev. 2009, 109, 3561-3598. (c) Batiste, L.; Chen, P. Coinage-Metal Mediated Ring Opening of cis-1,2-Dimethoxycyclopropane: Trends from the Gold, Copper, and Silver Fischer Carbene Bond Strength. J. Am. Chem. Soc. 2014, 136, 9296-9307.

(32) Nemcsok, D.; Wichmann, K.; Frenking, G. The Significance of $\pi$ Interactions in Group 11 Complexes with N-Heterocyclic Carbenes. Organometallics 2004, 23, 3640-3646.

(33) Jerabek, P.; Roesky, H. W.; Bertrand, G.; Frenking, G. Coinage Metals Binding as Main Group Elements: Structure and Bonding of the Carbene Complexes $\left[\mathrm{TM}(\mathrm{cAAC})_{2}\right]$ and $\left[\mathrm{TM}(\mathrm{cAAC})_{2}\right]^{+}(\mathrm{TM}=$ $\mathrm{Cu}, \mathrm{Ag}, \mathrm{Au})$. J. Am. Chem. Soc. 2014, 136, 17123-17135.

(34) Landis, C. R.; Hughes, R. P.; Weinhold, F. Bonding Analysis of $\mathrm{TM}(\mathrm{cAAC})_{2}(\mathrm{TM}=\mathrm{Cu}, \mathrm{Ag}$, and $\mathrm{Au})$ and the Importance of Reference State. Organometallics 2015, 34, 3442-3449.

(35) Fulmer, G. R.; Miller, A. J. M.; Sherden, N. H.; Gottlieb, H. E.; Nudelman, A.; Stoltz, B. M.; Bercaw, J. E.; Goldberg, K. I. NMR Chemical Shifts of Trace Impurities: Common Laboratory Solvents, Organics, and Gases in Deuterated Solvents Relevant to the Organometallic Chemist. Organometallics 2010, 29, 2176-2179.

(36) Ball, R. G.; Graham, W. A. G.; Heinekey, D. M.; Hoyano, J. K.; McMaster, A. D.; Mattson, B. M.; Michel, S. T. Synthesis and Structure of Dicarbonylbis $(\eta$-pentamethylcyclopentadienyl $)$ diiridium. Inorg. Chem. 1990, 29, 2023-2025.

(37) Çetinkaya, E.; Hitchcock, P. B.; Küçükbay, H.; Lappert, M. F.; Al-Juaid, S. Carbene complexes: XXIV. Preparation and Characterization of Two Enetetramine-derived Carbenerhodium(I) Chloride Complexes $\mathrm{RhCl}\left(\mathrm{L}^{\mathrm{R}}\right)_{3}$ and $\left[\mathrm{RhCl}(\mathrm{COD}) \mathrm{L}^{\mathrm{R}}\right]\left(\mathrm{L}^{\mathrm{R}}=\mathrm{dCN}(\mathrm{Me}) \mathrm{Cu}-\right.$ $\left(\mathrm{CH}_{4} \mathrm{CNMe}-\mathrm{o}\right)$ and the Preparation and $\mathrm{X}$-ray Structures of the Enetetramine $\mathrm{L}_{2}{ }^{\mathrm{R}}$ and its Salt $\left[\mathrm{L}_{2}{ }^{\mathrm{R}}\right]\left[\mathrm{BF}_{4}\right]_{2}$. J. Organomet. Chem. 1994, 481, 89-95.

(38) (a) Liske, A.; Verlinden, K.; Buhl, H.; Schaper, K.; Ganter, C. Determining the $\pi$-Acceptor Properties of N-Heterocyclic Carbenes by Measuring the ${ }^{77} \mathrm{Se}$ NMR Chemical Shifts of Their Selenium Adducts. Organometallics 2013, 32, 5269-5272. (b) Engl, P. S.; Senn, R.; Otth, E.; Togni, A. Synthesis and Characterization of NTrifluoromethyl N-Heterocyclic Carbene Ligands and Their Complexes. Organometallics 2015, 34, 1384-1395.

(39) Nakayama, J.; Sugiura, H.; Hoshino, M. Reaction of 1,3Benzodithiol-2-ylidenes with Elemental Sulfur and Selenium: a Convenient Preparation of 2-Thioxo- and 2-Selenoxo-1,3-benzodithioles. Tetrahedron Lett. 1983, 24, 2585-2588.

(40) The common procedure for the synthesis of $\mathrm{Ag}$ carbene complexes using silver oxide in the presence of a hydroxide base and the carbene precursor salt failed. Instead, only the carbene dimerization product DBTTF was observed. The synthesis of benzodithiolium chloride, which would have allowed the exclusive use of $\mathrm{Ag}_{2} \mathrm{O}$ (and thus circumvention of the use of a hydroxide base), was also not successful.

(41) Becke, A. D. Density-functional thermochemistry. III. The role of exact exchange. J. Chem. Phys. 1993, 98, 5648-5652.

(42) Frisch, M. J.; Trucks, G. W.; Schlegel, H. B.; Scuseria, G. E.; Robb, M. A.; Cheeseman, J. R.; Scalmani, G.; Barone, V.; Mennucci, B.; Petersson, G. A.; et al., Gaussian 09, Rev. A.1; Gaussian, Inc.: Wallingford, CT, USA, 2009.
(43) (a) ADF2014; SCM, Theoretical Chemistry, Vrije Universiteit: Amsterdam, The Netherlands; http://www.scm.com. (b) te Velde, G.; Bickelhaupt, F. M.; Baerends, E. J.; Fonseca Guerra, C.; van Gisbergen, S. J. A.; Snijders, J. G.; Ziegler, T. J. Comput. Chem. 2001, 22, 931-967. (c) Fonseca Guerra, C.; Snijders, J. G.; te Velde, G.; Baerends, E. J. Towards an order- N DFT method. Theor. Chem. Acc. 1998, 99, 391-403.

(44) Vosko, S. H.; Wilk, L.; Nusair, M. Accurate Spin-Dependent Electron Liquid Correlation Energies for Local Spin Density Calculations: a Critical Analysis. Can. J. Phys. 1980, 58, 1200-1211.

(45) Becke, A. D. Density-Functional Exchange-Energy Approximation with Correct Asymptotic Behavior. Phys. Rev. A: At., Mol., Opt. Phys. 1988, 38, 3098-3100.

(46) Perdew, J. P. Density-Functional Approximation for the Correlation Energy of the Inhomogeneous Electron Gas. Phys. Rev. B: Condens. Matter Mater. Phys. 1986, 33, 8822-8824.

(47) Grimme, S.; Ehrlich, S.; Goerigk, L. Effect of the Damping Function in Dispersion Corrected Density Functional Theory. J. Comput. Chem. 2011, 32, 1456-1465.

(48) (a) Versluis, L.; Ziegler, T. The Determination of Molecular Structures by Density Functional Theory. The Evaluation of Analytical Energy Gradients by Numerical Integration. J. Chem. Phys. 1988, 88, 322-328. (b) Fan, L.; Versluis, L.; Ziegler, T.; Baerends, E. J.; Ravenek, W. Calculation of Harmonic Frequencies and Harmonic Force Fields by the Hartree-Fock-Slater Method. Int. J. Quantum Chem. 1988, 34, 173-181.

(49) van Lenthe, E.; Ehlers, A. W.; Baerends, E. Geometry Optimizations in the Zero Order Regular Approximation for Relativistic Effects. J. J. Chem. Phys. 1999, 110, 8943-8953.

(50) (a) Morokuma, K. Why Do Molecules Interact? The Origin of Electron Donor-Acceptor Complexes, Hydrogen Bonding and Proton Affinity. Acc. Chem. Res. 1977, 10, 294-300. (b) Ziegler, T.; Rauk, A. On the Calculation of Bonding Energies by the Hartree Fock Slater Method. Theor. Chim. Acta 1977, 46, 1-10. (c) Ziegler, T.; Rauk, A. $\mathrm{CO}, \mathrm{CS}, \mathrm{N}_{2}, \mathrm{PF}_{3}$, and $\mathrm{CNCH}_{3}$ as $\delta$ donors and $\pi$ Acceptors. A theoretical study by the Hartree-Fock-Slater transition-state method. Inorg. Chem. 1979, 18, 1755-1759.

(51) Sheldrick, G. M. A Short History of SHELX. Acta Crystallogr., Sect. A: Found. Crystallogr. 2008, 64, 112-122. (SHELXS-97)

(52) Sheldrick, G. M. Crystal Structure Refinement with SHELXL. Acta Crystallogr., Sect. C: Struct. Chem. 2015, C71, 3-8. (SHEXL2014)

(53) Krause, L.; Herbst-Irmer, R.; Sheldrick, G. M.; Stalke, G. M. Comparison of Silver and Molybdenum Microfocus X-ray Sources for Single-crystal Structure Determination. J. Appl. Crystallogr. 2015, 48, 3-10. (SADABS) 